

IZA DP No. 9168

Parental Time Investments in Children:

The Role of Competition for University Places in the UK

Almudena Sevilla

Cristina Borra

July 2015 


\title{
Parental Time Investments in Children: The Role of Competition for University Places in the UK
}

\author{
Almudena Sevilla \\ Queen Mary, University of London \\ and IZA \\ Cristina Borra \\ University of Seville
}

Discussion Paper No. 9168

July 2015

IZA

P.O. Box 7240

53072 Bonn

Germany

Phone: +49-228-3894-0

Fax: +49-228-3894-180

E-mail: iza@iza.org

Any opinions expressed here are those of the author(s) and not those of IZA. Research published in this series may include views on policy, but the institute itself takes no institutional policy positions. The IZA research network is committed to the IZA Guiding Principles of Research Integrity.

The Institute for the Study of Labor (IZA) in Bonn is a local and virtual international research center and a place of communication between science, politics and business. IZA is an independent nonprofit organization supported by Deutsche Post Foundation. The center is associated with the University of Bonn and offers a stimulating research environment through its international network, workshops and conferences, data service, project support, research visits and doctoral program. IZA engages in (i) original and internationally competitive research in all fields of labor economics, (ii) development of policy concepts, and (iii) dissemination of research results and concepts to the interested public.

IZA Discussion Papers often represent preliminary work and are circulated to encourage discussion. Citation of such a paper should account for its provisional character. A revised version may be available directly from the author. 


\section{ABSTRACT \\ Parental Time Investments in Children: The Role of Competition for University Places in the UK ${ }^{*}$}

We use novel diary surveys coupled with universities' administrative student data for the last three decades to document that increased competition for university places at elite institutions in the United Kingdom contributes to explain growing gaps in time investments between college and non-college educated parents. Competition for university places in the UK grew significantly during the 1980s and early 1990s, and gradually diminished afterwards. We find that the gap in time investments by college and non-college educated parents and their children widened up precisely during this first period, especially in terms of human capital enhancing activities.

JEL Classification: J13, J24

Keywords: parental time investments, children, college competition

Corresponding author:

Almudena Sevilla

School of Business and Management

Queen Mary University of London

Francis Bancroft Building, Mile End Road

London E1 4NS

United Kingdom

E-mail: a.sevilla@qmul.ac.uk

\footnotetext{
* This work was funded by the ESRC under grant ES/K003127/1. This paper has benefited from comments provided by discussants and participants at the American Economic Association Annual Meeting, the Institute of Education, Royal Holloway, the European Society of Population Economics Conference, and the European Association of Labour Economists Meeting. We would like to thank Andrew Abbott for providing the 19961999 data on average students' entry scores by institution. Any remaining errors are our own.
} 


\section{Introduction}

Parental time has important implications in explaining children's adult life outcomes, and plays an important role in the intergenerational transmission of human capital (e.g., Del Boca et al., 2014; Fiorini and Keane, 2014; Heckman and Cunha, 2007). Understanding whether there is a growing inequality in the time parents spend with their children and its likely causes is crucial for child development and for policies aimed at reducing inequality. This paper uses 24-hour UK time diary surveys, coupled with novel administrative student data on college admissions and entry examination scores over the past three decades, to explore whether competition for college slots at elite universities can explain the diverging trends in time investments by parents with different educational attainments.

From a theoretical perspective the relationship between parental education and time spent with children can be rationalized using a simple economic model of parental time allocation where individuals derive utility from home-produced goods, leisure goods, and well-cared-for children, subject to the childcare production function and the usual time and budget constraints (see Guryan et al., 2008). Under this theoretical framework, higher returns to investment in children from college-educated parents (either because children of college-educated parents have greater potential and opportunities, or because college-educated parents are more efficient in the production of human capital, see Moav, 2005 and Adhvaryu and Nyshadham, 2014) may result in college-educated parents investing more time in their children relative to non-college educated parents. On the basis of a similar theoretical framework, Ramey and Ramey (2010) document that in the United States the sharp increase in parental time investments, particularly in children's extra-curricular activities on the part of college-educated parents, coincided with an increase in competition for college slots at elite universities driven by an exogenous increase in the number of 18 years old.

Using five 24-hour diary surveys covering 1974-2005, we document a divergence in time investments by parental education until the mid 1990s, and a convergence towards 2005. Whereas in the 1970s college educated mothers devoted about 40 minutes per week more and college educated fathers (ten more minutes per week than their less educated counterparts), by the mid 1990s college educated parents had increased the time they spent with their children by twice as much as parents with non-college education (with gaps reaching three and a half hours per week for mothers and almost one hour per week for fathers). By the end of the period parental time had 
increased three fold (from an average two hours per week), and all parents invested relatively the same amount of time in children regardless of their education levels.

More detailed information on the type of parental time investment activity available in the 1974, 1983, and 2000 time diary surveys reveals that although at the end of the period parents spent roughly the same amount of time with their children independently of their educational levels, this convergence did not occur for time spent in educational activities. In particular, by the early 2000s college educated mothers spent three times as much (half an hour a week more) in educational time than non-college educated mothers. Evidence from parents is consistent with children's time use diary responses. Children's homework time almost tripled from an average of two and a half hours per week in the 1970s to more than seven hours per week in the 2000s, particularly for children from college-educated parents. Whereas in the 1970s children devoted the same amount of time to homework regardless of their parents educational background, at the end of the period children from more educated family backgrounds spent four more hours doing homework than children from less educated family backgrounds.

Previous literature has suggested several theories to explain why higher parental educational attainment may be associated with larger parental time investments. Additional tests reveal that the key features in the trends in parental time investments (the timing, the type of activities, and the educational gradient component) are robust after controlling for household income, work status, changes in the composition of the educated population, and selection into parenthood. We also use additional data from the International Crime Victims Survey, the European Values Study, and the World Values Survey to estimate trends in parents' safety concerns and parenting values. We find that neither trends in safety concerns nor trends in parenting values for college and non-college educated parents match the trends in the education gradient in parental time investments that we document.

The last part of the paper uses administrative data from the Universities Statistical Record, the Higher Education Statistical Agency, and Times Higher Education Supplement to show matching trends in competition for college slots at elite universities and the education gradient in parental time investments. The United Kingdom shares many of the competitive college admissions features with the United States. As in the United States, the UK has a well-defined core of elite universities and a national application process, which is centrally coordinated. Returns to attending elite universities in both countries are also remarkably similar at around 6 per cent (Abbott and Leslie, 2004; Bound et al., 2009; Hoxby, 2009; Hussain et al., 2009; Chevalier, 2014). 
We document that coincident with the trends in time investments by parents of different educational attainment, the proportion of students securing a slot at elite institutions decreased between 20 and 15 per cent, and average relative entry qualifications increased almost twofold from the mid 1970s to the mid 1990s. Afterwards, competition for college slots at elite universities decreased both in terms of increases in the proportion of students entering these institutions and in terms of decreases in their relative entry qualifications. Despite declines in competition for college slots after the mid 1990s competition levels were higher in 2000 than in the 1970s. These higher competition levels are consistent with the relative increase in parental time investments in educational activities documented for college-educated parents, as well as increases in homework and study time by children from college-educated parents between the mid 1970s-1980s and the early 2000s. The fact that UK college admission processes are based on previous academic performance to a larger extent than US processes (Jerrim et al., 2012), may explain why collegeeducated parents and their children invest in more intensive educational activities in the UK while they focus on extra-curriculum activities in the US (Ramey and Ramey, 2010).

This paper adds to three strands of the economics literature. First, we contribute to furthering our understanding of the relationship between competition for college slots and parental time investments by showing the generalization of Ramey and Ramey’s (2010) results beyond the US, and their implications for college admissions policies more generally. Second, by documenting the diverging patterns for children and parents from different educational backgrounds over time in the UK and the US, we also complement the growing literature on the role of human capital investments in shaping intergenerational inequality (for recent examples see Del Boca et al., 2014; Fiorini and Keane, 2014). Third, by gathering and documenting for the first time unique evidence on the competition for slots at elite universities in the UK over three decades, we also add to the literature on inequality in university access in the UK (Dearden et al., 2011; Machin and Vignoles, 2004; Blanden and Machin, 2004; Chowdry et al., 2013; Bhattacharya et al., 2012).

The paper is organized as follows. Section 1 documents trends in parental time investments in the UK over the last decades, paying particular attention to the education gradient. Section 2 explores traditional explanations brought forward to explain the gap in parental time investments between parents with a college degree and non-college educated parents. Section 3 provides evidence that competition for slots at elite universities can explain the features in the trends of parental time investments in the UK over this period. Section 4 concludes. 


\section{Time Investments in the UK}

\subsection{Diary Data}

We use 24-hour time diary surveys from the harmonized UK Multinational Time Use Study Data set (UK MTUS), which covers three decades (1974, 1983, 1995, 2000, 2005) to provide a comprehensive picture of historical trends in parental time investments (see Table A1 in Appendix A for a description of these surveys). Most studies documenting long term trends in how individuals use their time are based on time-use diaries (Aguiar and Hurst 2007, Gimenez-Nadal and Sevilla 2012), which have become the preferred method to collect information on time spent on different activities just as money expenditure diaries have become the gold standard for describing consumption behavior.

The data have been harmonized to minimize differences in survey methodology, such as for example the lower number of episodes reported in 1995 and 2005 surveys (see Section I in the Appendix). The focus of our analysis is to compare parental time investments between educational groups over time, which should reflect changes in actual behaviour rather than changes in survey methodology, as there is no reason to believe that college and non-college educated parents are affected by data collection methods in systematically different ways.

For comparability with previous studies (see Ramey and Ramey, 2010) we select mothers and fathers aged 18 to 64 who are neither retired nor students whose youngest child is at least 5 years old to ensure that time devoted to childcare on the part of their parents is actually invested in older children. We use four measures of parental time investments: total time investments and general care, teaching care, and playing care. The classification of total time investments into finer categories is only possible in the 1983 and 2000 surveys, which provided a considerably large number of activities. ${ }^{1}$ Table A. 2 describes how these variables are constructed from the original activity codes. We also consider three categories of children's time use: travel time, time spent in school and other classes, and time spent in homework and study. These categories are constructed from the original activity codes as shown in Table A.3.

\footnotetext{
${ }^{1}$ We do not study childcare related travel time, as Guryan et al (2008) and Ramey and Ramey (2010) do, because we are not able to distinguish childcare related travel time from other travel time in the 1983 survey.
} 


\subsection{Trends in Parental Time Investments}

For comparability with US results, we estimate changes in education gradients in time investments over time by means of a simple OLS model as in Ramey and Ramey (2010) for a sample of 6,262 mothers and 4,831 fathers:

\section{(1) $C T_{i t}=\beta_{1} H_{i t}+H_{i t} \mathbf{T}_{\mathbf{t}} \boldsymbol{\beta}_{\mathbf{2}}+\mathbf{X}_{\mathbf{i t}} \boldsymbol{\beta}_{3}+\delta_{t}+\varepsilon_{i t}$}

Where $C T_{i t}$ is total time in hours per week in parental time investments by respondent $i$ in year t. $H_{i t}$ is a dummy variable that takes value one if educational attainment is some college or more, and $\mathbf{T}_{\mathbf{t}}$ is a vector of survey-year dummies. $\mathbf{X}_{\mathbf{i t}}$ is a set of controls to hold constant the demographic composition of the sample. In particular we include a vector of dummies controlling for the age group of the individual (ages 18-24, 25-34, 35-44, 45-54, and 55-64), marital status, the number of children, the number of children squared, and a vector of dummies to control for the day of the week the diary was reported (reference Sunday). Descriptive statistics are provided in Table A.4. Results hold when only controlling for age, as in Ramey and Ramey's (2010) benchmark specification. We also include survey-period fixed effects $\delta_{t}$ to account for long-term changes in attitudes towards children from both college-educated and less-than-college educated individuals. $\varepsilon_{i t}$ is the error term clustered at the survey level. MTUS proposed weights are used to ensure population together with day of the week and seasonal representativeness, and assign zero weights to low quality diaries, i.e. diaries having more than 90 minutes of missing time, fewer than 7 episodes, missing two or more of four basic activities, or being filled by a diarist of unknown age or sex.

Results from estimating Equation (1) for mothers’ weekly total time investments are presented in Column 1 of Table 1. The average amount of time spent by mothers with their children increased almost six hours per week from 1974 to 2005 (Column 1 of Panel A). Trends in the education gradient in time investments in Panels B and C reveal a divergence in time investments by parental education until the mid 1990s, fading away towards the end of the period. Whereas in the 1970s college educated mothers devoted 40 minutes more per week than non-college educated mothers to childcare, the gap in maternal time investments had relatively increased to more than an hour per week in 1983 and, by 1995, college educated mothers invested 3.5 more hours per week than their non-college educated counterparts. Results from estimating Equation 1 for the sample of 
fathers in column 5 of Table 1 show that the education gradient for fathers followed a similar pattern to the pattern found for mothers, reaching about one hour per week in 1995, and gradually decreasing afterwards. As shown in Figure A.1 in the Appendix the adjustment in parental time with children took place through changes in leisure time and unpaid work for women, and paid work and housework for men.

Available information on the type of time investment activity from the 1983 and 2000 surveys suggests that, although at the end of the period mothers spent roughly the same amount of time with their children independent of their educational levels, this convergence did not occur for time spent in educational activities. In particular, Columns 2 and 3 of Table 1 show that whereas in 1983 college educated mothers devoted about 45 minutes more per week to general care and 10 minutes more to teaching care, by 2000 college educated mothers spent 15 minutes more in general care relative to non-college educated mothers, while college-educated mothers invested half an hour more in educational childcare (e.g. teaching children, helping them with homework) than non-college educated mothers. We also find increases in the differential time devoted by college-educated fathers over their non-college counterparts to educational activities during this period, although the magnitudes are lower (Column 6 of Table 1). Previous literature has noted that the share of household expenditures that goes to children increases with income and, therefore, education (Bonke and Browning, 2011). Here we also document a growing inequality in time devoted to children’s educational activities by parental education.

\subsection{Evidence from Children's Time Use}

Ramey and Ramey (2010) find that an important part of the divergence in time investments by parents with different educational attainment in the US is due to travel and activities of older children and argue that this fact is a reflection of children from more educated family backgrounds engaging in more extracurricular activities that may be important for securing a place at a selective university, as suggested by Bound et al. (2009) and Avery and Levin (2010). In the UK we have shown a sustained gap in educational time between college educated and less than college educated parents which is consistent with the relative larger weight of previous academic performance in deciding college admission in the UK compared to the US (Jerrim et al., 2012; Bhattacharya et al., 2012). We look at children's diary records to test whether the trends in the education gradient in parental time investments of Table 1 are consistent with a differential behaviour on the part of children across educational backgrounds. In particular we look at 
children's time devoted to travel, school and other classes, and homework and study (see Tables A.3 and A.5 in the Appendix for the activities included in each category in the US and the UK surveys). ${ }^{2}$ For the US, we use the 1985 Americans' Use of Time Project and the 2003-2008 American Time Use Survey (ATUS) which offer information on maternal education for the children who fill out the diaries, and select children aged 15 to 17 years old, as ATUS surveys individuals from 15 years old onwards. For the UK we include observations from the 1974, 1983, and 2000 surveys, which are household surveys and offer information on maternal education for the children who fill out the diaries, and select children between 14 and 17 years old for consistency across surveys, given that the 1983 survey’s age range is 14 years old onwards.

We first confirm Ramey and Ramey’s (2010) results using children's responses to the time use diary. Columns 1 to 3 in Table 2 document that, consistent with college educated parents' increases in time devoted to travel and activities as reported by Ramey and Ramey (2010), children from college educated backgrounds increased the time devoted to travel and school and other classes with respect to their less educated background counterparts, while the gap in time devoted to homework and study between children of different educational groups closed. In particular, as shown in Panels A and B of Column 1 in Table 2, whereas in the mid 1980s there was no appreciable difference in the time devoted to travel across education groups, by the end of the period children from college educated backgrounds spent almost one hour more per week than children from non-college educated backgrounds. Similarly, whereas in the mid 1980s children from non-college educated backgrounds spent about 4 more hours per week to school and other classes than children from college educated backgrounds, by the end of the period both groups of children attended school and other classes for similar amounts of time in a given week (Panels A and B of Column 2 in Table 2). In contrast with increasing education gradient in travel and structured activity time, Panels A and B of Column 3 show a convergence in the education gradient in homework and study time from about three hours per week at the beginning of the period to over one hour at the end of the period. Overall this evidence is consistent with college educated parents increasingly devoting more time to organize children's extracurricular activities rather than to helping them with homework as emphasized by Ramey and Ramey (2010), in line

\footnotetext{
${ }^{2}$ There is an additional category of free outdoor sports which shows no positive gap for children of college educated backgrounds either in the US or the UK.
} 
with the relative importance of extracurricular accomplishments in gaining access to selective higher education institutions in the US (Bound et al., 2009; Avery and Levin, 2010).

Columns 4 to 6 in Table 2 show the corresponding results for UK children. Consistent with the evidence presented for parental time investments in Table 1, and in contrast to the evidence presented in Columns 1-3 for US children, in the UK children from college educated backgrounds increasingly spend more time in human capital enhancing activities, such as time devoted to homework and study. In particular, Panels A and B in Column 6 show that whereas in the 70s children devoted the same amount of time to homework regardless of their parents' educational background, from the mid 1980s onwards children from more educated family backgrounds spent four hours per week doing homework, almost twice as much time as children from non-college educated backgrounds. As shown in Panels A and B in Column 5 the increase in the gap in homework time was only partially offset by decreases in the gap in time at school and other classes. Children from college educated backgrounds also show a positive gap of four hours per week in school and other classes compared to children from non-college educated backgrounds, however the gap decreased about two hours from the mid 1970s to the mid 1980s. Panels A and B in Column 4 also show a positive education gradient in children's travel time of about half an hour that emerged in the mid-80s.

The conclusions from Tables 1 and 2 are twofold. First, compared to the US where gaps in time investments between college and non-college educated mothers grew from the mid 1990s onwards to over six hours (Ramey and Ramey 2010), in the UK college-educated parents increased the time they spent with their children by twice as much as non-college educated parents from the mid 1980s until the mid 1990s, but the gap closed gradually thereafter. Second, compared to the evidence for the US where increases in parental time investments for college-educated parents focused on children's extra-curricular activities, we document that from the mid 1980s onwards until 2000, when finer data on diary activities is collected, college-educated parents and their children increasingly spent relatively more time on human capital enhancing activities than lessthan college educated parents. The relative weight placed on educational support by parents and children from more educated backgrounds in the UK over this period shown in Table 2 contrasts with the findings for the US. Ramey and Ramey (2010) found that over the 1987-2000 period college-educated parents increasingly spent more time than non-college educated parents in "general" care and "travel and activities", as opposed to educational activities. Our own analysis using children's diaries for the US corroborates this finding. Whereas children's time devoted to 
school and other classes and active sports participation almost doubled, there is no increasing divergence in the time spent in homework by parental educational background for American children over this period.

\section{Conventional Explanations}

In this section we first test whether the non-monotonic trend in parental time investments in the UK still holds after controlling for selection into parenthood, household income, work status, and changes in the composition of the educated population. The selection into parenthood hypothesis suggested by Bianchi et al. (2006) and Ramey and Ramey (2010) argues that individuals who decide to become parents, especially college educated individuals, may have a greater motivation to invest heavily in children. Income effects may also explain why more educated parents spend more time with their children, as long as children are considered luxury goods whose consumption increases with income (Guryan et al., 2008). Different time investments by parents with different levels of education could also vary with working arrangements if, for example, jobs undertaken by college educated mothers offer more flexible working schedules and better childcare provisions (Ramey and Ramey, 2010; Sayer and Gornick, 2012). Alternatively, it could be that college educated mothers decide to opt out of the labour force to a greater extent than less-than college educated mothers (Goldin, 2006). ${ }^{3}$ Composition effects may also explain trends in the gap in time investments by parental education if the marginal college educated parent at the beginning of the period, when just 10 percent of our sample had at least some college, differs from the marginal college educated parent at the end of the period, when 30 percent of our sample had at least some college. For example, those going to college in the 2000s may value education more than the minority going to college in the 1970s, explaining increases in parental time investments (Aguiar and Hurst, 2007).

Other explanations based on perceptions on safety and parenting values have also been used to explain the education gradient. The fact that college-educated parents may be more concerned about children's physical safety than non-college educated parents may explain why collegeeducated parents spend more time accompanying their children in their activities (Sayer et al., 2004a). Similarly, college-educated parents may subscribe to a more time-intensive parenting style than non-college educated parents (Sayer et al., 2004b; Sullivan, 2010; Wight et al., 2009). For

\footnotetext{
3 College-educated mothers did not suffer from unemployment shocks to a larger extent than non-college educated mothers, particularly during the early to mid 1990s when the education gradient in time investments increased (Evans 1998; OECD 2011).
} 
example, Lareau (2003) argues that middle class parents tend to conform to what she terms the concerted cultivation approach, which involves time-intensive parenting through reasoning with children and arranging children's extracurricular activities. In the same vein a recent book by Putnam (2015) contends that educated parents engage in a non-stop dialogue with their children, helping them to make decisions. In contrast to college-educated parents, working class parents tend to follow a less time intensive "natural growth approach” (in Lareau’s (2003) terminology), where children spend most of their free time playing with friends, unsupervised by adults. Working class parents use directives to control children's behaviour, which, as emphasized by Putnam (2015), may save them time in the short run but prevents the kids from acquiring independence skills in the long run.

\subsection{The Role of Selection Effects, Income, Working Arrangements, and Composition Effects}

Columns 1 and 2 in Table 3 show the same pattern of time investments by education as in Table 1 when considering non-parents to account for selection effects (see Ramey and Ramey (2010)). Against the selection hypothesis, including non-parents in the sample does not eliminate differences in childcare time across education groups. Columns 3 and 4 in Table 3 show that income is not a significant determinant of parental time investments, and that trends in the education gradient remain virtually unchanged with respect to the results in Table 1 . Columns 5 and 6 in Table 3 show that results in Table 1 remain for both working and non-working mothers, which suggests that neither changing working practices nor opting out nor unemployment can be behind the trends in parental time investments by educational attainment in the UK. ${ }^{4}$ Following Aguiar and Hurst (2007) Columns 7 and 8 in Table 3 show that results in Table 1 are robust to using an alternative measure of highly educated $H_{i t}$ that defines as highly educated the top 30 per cent in all the surveys (30 percent in 1974, 31 percent in 1983, 26 percent in 2000 and 27 percent in 2005). We find the same pattern of time investments by education in Table $1 .{ }^{5}$

\footnotetext{
${ }^{4}$ Note that sample sizes in the 1995 and 2005 time use surveys are too small to provide information by maternal working status.

${ }^{5}$ Following Aguiar and Hurst (2007), the new education dummy takes value 1 if an individual's educational attainment corresponds to having completed secondary education or more if the respondent belonged to the 1974 and 1983 surveys, and some college or more (as before) for respondents in later surveys.
} 


\subsection{The Role of Safety Concerns}

We formally test for the possibility that safety concerns may be behind the trends in the education gradient by estimating a model similar to that in Equation (1) using data from the International Crime Victims Survey (ICVS) for the years 1989, 1996, 2000, and 2004 (van Kesteren, 1989-2005). We use the question "What would you say are the chances that over the next twelve months someone will try to break into your home?" (which has been part of ICVS questionnaire since 1989) and construct a variable of fears of house burglary by coding responses as a dummy (1, if the answer to the question is very likely; zero, otherwise). We also use "How safe do you feel when walking alone on the street after dark?” (which was first answered in the UK in 1996) and construct a variable of feelings of unsafety on the street by coding responses as a dummy (1, if the answer to the question is "very unsafe", and zero otherwise). As in Equation (1), our main independent variable is whether the respondent completed more than the 12 years of education, coinciding with the definition from the MTUS used in our main analysis. We select all individuals aged 18-65 who are not student or retired. Descriptive statistics are provided in Table A.6 in the Appendix.

Trends in safety concerns for college and non-college educated parents shown in Panel C in Table 4 do not seem to match trends in the education gradient shown in Table 1 . We find that the safety fears of college-educated individuals are consistently lower than those of their non-college educated counterparts throughout the period. More importantly, there is no sign of convergence, as college-educated individuals increasingly feel safer than non-college educated individuals over this period. For instance, safety fears about burglary of college educated women were 2 percentage points higher than those of their non-college educated counterparts in 1989, but by the mid 2000s they were 8 percentage points lower (Panel C of Column 1 in Table 4). Similarly, the proportion of college educated women feeling very unsafe after dark was between 3 and 6 percentage points less than the corresponding proportion of non-college educated women throughout the mid 1990s-mid 2000s period (Panel C of Column 2 in Table 4). We find similar trends for college and non-college educated men in Panel $\mathrm{C}$ of Table 4. The fact that we fail to find heightened safety fears on the part of college-educated parents suggests that safety concerns cannot explain the trends in parental time investments by educational attainment documented in Section 1. 


\subsection{The Role of Parenting Values}

We test whether parental time investments in children by educational attainment can be accounted for by different parenting attitudes by estimating a model similar to that in Equation (1) using information from the European Values Study (1981, 1990, and 1999) and World Values Survey Data, 2005 (WVS, 2005-2007) for a sample of parents aged 18-65 who are not student or retired. In these surveys respondents are presented with a list of qualities that "children can be encouraged to learn at home”, and are asked to choose up to five qualities that they consider to be particularly important. The qualities are independence, hard work, feeling of responsibility, tolerance and respect, thrift, saving money and things, determination, perseverance, religious faith, and obedience. Descriptive statistics are provided in Table A.7 in the Appendix. We use principal component analysis to summarize these measures in one single parenting values index. For both men and women, the first principal component index puts a high negative weight on obedience and a high positive weight on independence and imagination (see Table A.8 in the Appendix). We follow the economics literature and interpret lower values in the parenting values index as indicative of a less time-intensive authoritarian parenting (Doepke and Zilibotti, 2014). Similarly, we interpret higher values of the parenting values index to be more in line with the more time intensive concerted cultivation parenting approach, which places more emphasis in reasoning rather than directing children’s behaviour (Lareau, 2003; Putnam, 2015).

Panels $\mathrm{B}$ and $\mathrm{C}$ in Table 5 show that trends in parenting values by parents with different educational attainment do not match the trends in the education gradient in time investments shown in Table 1. Parenting values that stress independence over obedience were more popular among college educated mothers at the beginning of the period and college educated mothers were located on average one tenth of a standard deviation higher in the parenting values index distribution (between four percentiles higher) than non-college educated mothers. Similarly to the trends in the education gradient in maternal time investments in Table 1, around the mid 1990s, the education gradient in maternal parenting values increased twofold and college educated mothers were now located about one twentieth of a standard deviation over their non-college educated counterparts. Yet after 1990 this differential view of parenting remained virtually constant failing to decline as the gap in maternal time investments by education in Table 1 shows.

With respect to fathers we fail to find a steep rise in the different attitudes between the college and the less than college educated around the mid 1990's, even though at the end of our period of 
analysis both fathers' behaviour towards children and parenting attitudes seem indistinguishable by educational attainment. Note also that this parenting explanation would have similar impacts in parental behaviour independent of the age of the youngest child. Table A.9 in the Appendix shows that trends in time investments by education for families with youngest child under 5 are not coincident with the trends in time investments by education for families with youngest child over 5, as presented in Table $1 .^{6}$ Both the trends in parenting values by education and the fact that we find different trends in the education gradient in time investments by age of youngest child do not support parenting values as a plausible explanation for the trends in parental time with children.

\section{The Role of College Competition in the UK}

The theories brought forward in the literature and discussed in Section 2 do not seem to be able to explain the non- monotonic trends in the education gradient on parental time with children in the UK over this period. In this section we document that the patterns in the trends in parental time investments shown in Tables 1 and 2 (the non-monotonic trend, the type of activities, and the educational gradient component), closely match the trends in the competition for college slots at elite universities in the UK. To that end we gather administrative data at the university level and construct a long historical data set of student enrolment numbers and entry examination scores over a period of more than three decades

\subsection{Competition for College: Data and Measures}

To study competition for college admissions we first rely on enrolment information from the Universities' Statistical Record (USR), and the Higher Education Statistics Agency (HESA). The USR collected annual individual student records for the full population of undergraduate students at university from 1974/75 to 1993/94 (the year HESA was established). The full dataset contains information on about 6,200,000 students - about 270,000 per cohort, whereas HESA provides

\footnotetext{
${ }^{6}$ As an additional explanation, the results in Table 1 could be due to cohort effects. We find the largest education gradients for parents with the youngest child under 5 for the 1983 survey (Columns 1 and 2 in Table A.7) and the largest education gradient for parents with the youngest child over 5 for the 1995 survey (Columns 1 and 5 in Table 1). There could be a cohort of driven, motivated college educated parents that were devoting a large amount of time to childcare in the mid 1980s, when their youngest child was under 5, and afterwards in the mid1990s, when their youngest child was over 10. We estimate equation 1 in a restricted sample of families with youngest child between 5 and 10 years old (Columns 3 and 4 in Table A.7), leaving outside the sample those families who would have had children under 5 in the mid 1980s and over 10 in the mid1990s. We find the same pattern of education gradients in Columns 3 and 4 in Table A.7 and Columns 1 and 5 in Table 1 and rule out that our results are driven by cohort effects.
} 
university-level data on enrolment from 1994/95 onwards. Comparability across both datasets is assured by selecting from USR full-time undergraduate students, as defined by HESA (UK and foreign full-time students, plus students in sandwich years and spending an obligatory year away from the university, e.g., language students abroad).

We then use information on average entry qualifications by institution from USR student-level information on Advanced (A)-level qualifications from 1974/75 to 1993/94 and from Times Higher Education Supplement (THES) 1996/97 to 1999/2000. ${ }^{7}$ There is no available student scores data from 2000 until 2007. ${ }^{8}$ Most UK applicants sit A-levels on three subjects at age 18 at the end of the two-year post compulsory education. Even if there exist different examination boards, the evaluation system is centrally coordinated and therefore average A-level scores are considered to be directly comparable across institutions (see Bhattacharya et al., 2012, among others). Most higher education institutions use grades in A-level qualifications as the main criteria for university entry, the other options being the Scottish Certificate of Higher Education and foreign qualifications (Walker and Zhu, 2008). We select from USR all UK undergraduate students reporting A-levels as entry qualifications, thus discarding observations from students entering university through the Scottish Certificate of Higher Education or foreign qualifications to calculate average A-level scores by institution for the years 1974/75 to 1993/94 that we merge to average A-level scores by institution from THES for the 1996/97 to 1999/00 period. Both USR and THES compute average scores by summing up scores from each student's 3 top A-level scores (an A score being 10 points, a B score being 8, a C score being 6, a D score being 4, and a E score 2 in USR and two points more, from 12 to 4, for A to E, in THES).

We consider two definitions of elite universities. Firstly, we look at ancient and civic universities traditionally considered elite universities in the UK (see Barnes, 1996). These institutions are those universities funded during the Middle Ages, namely Oxbridge (Oxford and Cambridge), the so-called ancient universities in Scotland (St. Andrews, Glasgow, Aberdeen, and Edinburgh), and civic universities founded in the major industrial cities of England before World War I (Birmingham, Liverpool, Manchester, Leeds, Sheffield and Bristol). Secondly, we also consider a more recent group of elite universities, the Russell Group. The Russell Group is an association of research-intensive UK universities created in 1994, generally regarded to be

\footnotetext{
${ }^{7}$ Data from Abbott and Leslie (2004) provided by the authors.

${ }^{8}$ HESA data on students' A-levels was only available from 2007 onwards, as indicated in e-mail communication.
} 
amongst the most prestigious universities in the UK (Anders, 2012; Chowdry et al., 2013). To focus on universities that may have been considered selective during our period of analysis, we focus on universities belonging to Russell Group founders (Birmingham, Bristol, Cambridge, Edinburgh, Glasgow, Imperial College London, Leeds, Liverpool, London School of Economics, Manchester, Newcastle, Nottingham, Oxford, Sheffield, Southampton, University College London, and Warwick), but results are robust to including later members. ${ }^{9}$

Our first measure of competition for elite university places is the unconditional probability of attending an elite institution, constructed as the ratio of the annual number of full-time undergraduate students attending elite institutions to the number of full-time undergraduate students attending pre-1992 universities. Whereas in the US students can apply to as many universities as they want, in the UK students can only apply to a fixed number of universities. As a result, elite universities in the UK receive fewer applications than non-elite institutions because only students who are sure to meet their strict entry standards apply to them (Abbott and Leslie, 2004). By focusing on actual slots we take into account the strategic behavior on the part of students getting a more accurate picture of college competition than a measure based on applications to acceptances (Bound et al., 2009).

In the spirit of Hoxby (2009), our second measure of competition for slots at elite universities is the relative entry qualifications of students admitted to elite universities compared to non-elite universities. We construct the ratio between the average A-levels entry score at elite institutions and the average A-levels entry score at all institutions, weighted by the proportion of UK students attending each institution. The rationale behind this measure is that increases in competition should be accompanied by increases in the selectivity of elite institutions, which should be reflected in higher average entry qualifications relative to non-elite universities (Hoxby, 2009). By comparing relative scores between elite and the rest of institutions we overcome recent criticisms on the declining standards in A-levels examinations and increasing scores over time (Coe and Tymms, 2008).

We limit the sample to pre-1992 universities in order to keep the number of universities constant throughout the period (the passage of the Further and Higher Education Act in 1992 granted university status to 48 former polytechnics, see Greenaway and Haynes, 2003). Our results

\footnotetext{
${ }^{9}$ Cardiff University and King's College London, in 1998, Queen's University Belfast, in 2006, and Durham, Exeter, Queen Mary University of London, and York, in 2012.
} 
continue to hold if post-92 universities are included (see Table A.10 in the Appendix, which shows total enrolment rates for elite universities, pre-1992 institutions, and all existing universities together with the proportion of students attending elite institutions). We also limit the sample to those higher education institutions included in THES database, which involves excluding the London Institute of Education, Birkbeck College London, UMDS London, University of Wales College of Medicine, and Open University. Our results for the period 1974-1994 follow when including these four universities in the analysis. Table A.11 shows average entry scores for elite universities, pre-1992 institutions, and all existing universities together with corresponding relative scores.

\subsection{College Competition and the Education Gradient in Parental Time Investments}

This section documents trends in the competition for college slots at elite universities by looking at enrolment rates and student entry examination scores at elite colleges in the UK over the last decades. We also show that trends in the competition for college slots at elite universities closely followed trends in the education gradient in parental time documented in Table 1, and the increasing trend in college-educated parents' teaching time and their children's homework and study time between the mid 1970s-1980s and the early 2000s in the UK.

In the US the secular increase in demand for college slots that led to increases in the competition at elite university places was mainly driven by demographic factors resulting from the rise in college-bound cohorts beginning in the mid 1990s. Compared to the US, in the UK changes in the demand for college slots responded in a greater extent to structural factors related to the regulation of the high education sector which resulted in increases in college competition up to the mid 1990s and decreases thereafter. In particular, the introduction in 1988 of the General Certificate of Secondary Education (GCSE), a national examination taken when students reach the age of 16 in specific subjects, resulted in a step-change of 40 per cent increase in the proportion of students staying on beyond the compulsory school leaving age from 51 per cent in the late 80s to 70 per cent in the late 90s (see Blanden and Machin, 2004). The reform was introduced to end the previous two-tier system separating children into high and low education streams, in which students could either take O (Ordinary) levels, if they aimed to stay beyond compulsory education, or the Certificate of Secondary Education if students did not want to pursue further education.

From the mid 1990s the number of university places showed a much slower rate of growth despite increases in the college education age population after 1998 (HEFCE, 2001). This slow 
down in university enrolment has been argued to be the result of demand-side factors rather than supply-side factors. On the demand-side, the stabilization in the proportion of pupils staying on beyond compulsory education remained fairly constant at about 70 per cent of total secondary students from the late 1990s onwards, and changes in student funding including the introduction of fees in 1998 (Greenaway and Hayness 2002, Dearden et al. 2008). On the supply side, although in 1993 the British Government introduced Maximum Aggregate Student Numbers (MaSN), a cap on the maximum number of students for which the university obtained funding, by the mid 1990s MaSN targets were persistently larger than actual recruitment, and in 2000-01, just before the abolition of this cap in England, some 14,465 funded places remained unfilled (HEFCE, 2001; Abbott and Leslie, 2004).

Panels A and B in Figure 1 show that up to the mid 1990s competition for college slots at elite universities increased relatively more than competition for college slots at other universities. Although the competition for elite universities slowed down after the mid 1990s, it stayed at relatively high levels with respect to competition levels in the 1970s. In fact, returns to graduating from an elite university increased fivefold from 1 to 6 per cent up to the mid 1990s, and remained fairly constant thereafter (Chevalier and Conlon, 2003; Chevalier, 2014).

In light of overall changes in student numbers, Figure 1 documents competition for college slots at elite universities. Panel A in Figure 1 shows that student enrolment rates rose relatively less in elite institutions than in other universities from the mid 1970s until the mid 1990s. In contrast, after the mid 1990s the proportion of students admitted to elite universities did not decrease (stayed fairly constant at 30 per cent at ancient and civic universities, and increased by about 6 per cent at Russell group universities). In particular, the proportion attending civic and ancient universities dropped by 20 per cent from about 38 per cent, while the proportion attending Russell group universities dropped by 15 per cent from about 45 per cent. These are similar decreases as in the US, where Bound et al. (2009) found that the probability of acceptance to a private selective institution, conditional on applying, decreased approximately by 23 per cent from mid 1980s to mid 2000s.

Similarly Panel B in Figure 1 shows that, compared to non-elite universities, average examination results for entry to elite universities increased almost two fold until the mid 1990s, and dropped thereafter. In particular, from being 7 per cent higher than non-elite universities in 1974 to 13 per cent higher in 1993 for ancient and civic universities, and from being 12 per cent higher in 1974, to 17 per cent higher for Russell group universities. Relative entry qualifications at 
ancient and civic universities decreased four percentage points from 16 to 12 per cent, while entry qualifications at Russell group universities decreased about three percentage points from 17 to 14 per cent from the mid 1990s to the early 2000s.

Panel C in Figure 1 shows a sticking correspondence between parental time investments as reported in Table 1 and competition for university places at elite institutions. In particular, from the mid 1970s to the mid 1990s the gaps in parental time investments by parental educational attainment increased (Panel C) coinciding with a decrease in the relative number of students attending elite institutions (Panel A), and an increase in entry qualifications of students attending elite universities relative to students attending non-elite universities (Panel B). Subsequently, from the mid 1990s onwards, while parental time investments by educational attainment converged (Panel C), the competition for college slots at selective universities did not increase (Panel A), and average entry qualifications of the students attending these universities decreased (Panel B).

Increases in college competition for university places at elite institutions over the 1970-2000 period also coincided with college-educated parents and their children increasingly spending relatively more time on human capital enhancing activities than less-than college educated parents in the UK as reported in Table 2 (as explained in Section 2, we do not have information about childcare activities for the 1995 and the 2005 time use surveys, so we cannot assess whether parental time investments in educational activities increased or decreased between the mid 1980s and the mid 1990s and from the mid 1990s onwards).

In line with Ramey and Ramey’s (2010) evidence for the US, our results suggest that children from more privileged backgrounds may have been more likely to compete for places at elite colleges also in the UK, shedding light on the underlying factors behind the high correlation between family background and examination scores in the UK (Jerrim et al., 2012). Compared to the US however, parents with a college degree in the UK seem to devote more time to humancapital enhancing activities, echoing qualitative evidence from the sociological literature emphasizing parents' anxiety for children's academic achievement and the expectation that parents help children at home after school in the UK (Reay, 2005). These distinctive aspects of UK parents' and children's behaviour could be rationalized by the different incentives parents face from the two educational systems. Despite sharing many features in the college admission process, both the UK and the US crucially differ in that college admission decisions are mainly based on students' prior educational qualifications and rarely on subjective assessments of motivation or performance at interview in the UK (Epple et al., 2006; Jerrim et al., 2012). In particular, as 
emphasized by Bhattacharya et al. (2012), admission decisions are usually made within a short period of time and, even in very selective universities such as Oxford and Cambridge where candidates are interviewed, admission tutors conduct standardized assessments based mainly on prior qualifications and aptitude test scores.

\section{3. $\quad$ Comparison of Trends in Education Gradients in Time Investments across UK Regions}

This section provides further suggestive evidence on the positive association between larger education gradients in time investments and higher competition for university places at elite institutions by comparing trends in parental time investments by educational attainment across UK regions with different competitive pressures. In particular we show that the increasing divergence in parental time investments between college and non-college educated parents until the mid 1990s, and the convergence thereafter, were mainly driven by parents in high competition regions.

In the UK students can apply for up to five institutions and face no restrictions with respect to where these institutions are located. Similarly, UK higher education institutions face no financial incentives with respect to the proportion of out-of-region British undergraduates, as all national students are treated homogenously (Hoare, 1991). However, most students study in their local region, 52\% in 2002 (McClelland and Gandy, 2012), a figure which is similar in magnitude to the 54.6 percentage of US "in-state" students in private colleges in 1994 (Hoxby, 1997). Existing evidence shows that distance is the strongest factor influencing university choice amongst those attending university. For example, a ten percent increase in home-to-university distance decreases the probability of attending that specific university by 8 to 15 percent (Gibbons and Vignoles, 2009). Faced by mobility constraints, student applicants who live in regions where elite universities are located must be subject to higher competitive pressures.

Using the regional information in the UK time diary surveys, we consider two alternative definitions of high-competition regions. First, we define regions of high competitive pressure as those where Oxford and Cambridge are located, which includes East of England and London and South West. A second definition of high competitive pressure regions considers those regions where ancient and civic universities are located (East of England, London and South West, North of England, and Scotland). ${ }^{10}$

\footnotetext{
${ }^{10}$ We investigated the possibility of using Russell Group universities' region of origin but given the wide coverage of the regional information in UK TUS we could not use it because of the low number of observations belonging to
} 
We estimate our model of Equation 1 in the four sets of samples: Oxbridge and non-Oxbridge regions and ancient-and-civic and non-ancient-and-civic regions. Columns 1 to 4 of Panel $\mathrm{C}$ in Table 6 show that our results in Table 1 are mainly driven by the differentiated behavior of college-educated and non-college educated mothers in high competition regions. In particular, education gradients in time investments by mothers in Oxbridge regions increased about eight hours per week from the mid 1980s to the mid 1990s, whereas education gradients of mothers in non-Oxbridge regions decreased about half an hour over that period. Similarly education gradients in time investments of mothers in ancient-and-civic regions increased about three hours per week from the mid 1980s to the mid 1990s whereas education gradients of mothers in non-ancient-andcivic regions remained virtually constant over that period. Afterwards education gradients for mothers in all groups of regions decreased and, by the end of the period, there hardly remains any difference in mothers' time investments by educational attainment. A similar result is found for fathers' education gradients in time investments, as shown in Columns 5 to 8 of Panel C in Table 6. Again, the results in Table 1 are driven by the differentiated behavior of college and non-college fathers in high-competition regions, either where Oxbridge universities are located (Column 5) o where ancient and civic universities are located (Column 7).

\section{Conclusion}

Consistent with evidence for the US, this paper finds that increased competition for university places at elite institutions in the United Kingdom contributes to explain growing gaps in parental time investments. Compared to US findings, the UK experience is in some ways more remarkable. Competition for university places in the United Kingdom grew during the 1980s and early 1990s to recede afterwards. We find that the education gradient in parental time investments widened precisely during this first period, especially in terms of educational and other human capital enhancing activities.

We rule out alternative theories aiming to explain why higher parental educational attainment may be associated with larger parental time investments. As noted by Ramey and Ramey (2010), most of these theories unfold broadly and gradually, whereas we document a sharp increase in the education gradient in parental time with children between the mid 1880s and 1990s, and the

non-Russell-Group regions. Sample sizes of high and low competition regions for the 1995 and 2005 surveys are low. Table A.12 in the Appendix shows that our results are robust to using only the 1974, 1983, and 2000 surveys. 
subsequent decline. Further evidence comparing trends in time investments by parental educational attainment across UK regions with different college competitive pressures shows that the increasing divergence in parental time investments between college and non-college educated parents until the mid 1990s and the convergence thereafter is mainly driven by parents in high competition regions.

Our results have implications for policy reform at the point of university entry. Expanding the number of slots at attractive colleges or modifying their acceptance rules to place greater emphasis on criteria that parents cannot directly influence may be desirable (see Ramey and Ramey, 2010). One possible low-cost intervention suggested in the literature would be to promote a widespread use of 'contextual' information in the university admission process (such as family income) when admitting prospective students (see Jerrim et al., 2012).

Alongside initiatives targeted to the university admission process, measures to help less educated parents prepare their children better to successfully compete in the university admission process would also be justified (see Cuhna et al., 2006). Prior school performance is one of the main drivers in explaining the under-representation of low and middle class students at selective higher education institutions (Jerrim et al., 2012), and there is rising evidence that achievement gaps of children from different educational backgrounds in the UK emerge during secondary school (Ermisch et al., 2012; Green et al., 2012). We find that by the end of the period children from more advantaged backgrounds benefit from more parental time in the form of educational activities relative to children from less educated backgrounds, which recent research has shown to increase children's test scores (see for example Fiorini and Keane, 2014). Raising subsidies for less educated parents, teaching them better parenting skills, and improving nursery care, are among the policy suggestions brought forward for the case of the US (Putman, 2015). Compared to the US, the UK admissions system places more weight on examination results and prior academic performance. Targeted measures designed to boost school performance for children from less advantaged families such as providing after-school homework clubs could be a way forward. 


\section{REFERENCES}

Abbott, A. and Derek L. (2004). "Recent Trends in Higher Education Applications and Acceptances". Education Economics, 12(1): 67-86.

Adhvaryu, A. and Nyshadham, A. (2014). "Endowments at Birth and Parents' Investments in Children”, The Economic Journal. doi: 10.1111/ecoj.12186.

Aguiar, M. and Erik H.( 2007). "Measuring Trends in Leisure: The Allocation of Time Over Five Decades,” Quarterly Journal of Economics, 122 (2007): 969-1006.

Anders, J. (2012). "The Link between Household Income, University Applications and University Attendance," Fiscal Studies, 33(2): 185-210.

Avery, C. and Levin, J. (2010). "Early Admissions at Selective Colleges," American Economic Review, 100(5): 2125-56.

Barnes, S. V. (1996). "England's Civic Universities and the Triumph of the Oxbridge Ideal” History of Education Quarterly, 36(3): 271-305.

Bhattacharya, D. Kanaya, S. and Stevens, M. (2012). "Are University Admissions Academically Fair?". Economics Series Working Papers 608, University of Oxford, Department of Economics.

Bianchi, S. M., John P. R., and Milkie, M. A.. (2006). Changing Rhythms of American Family Life, New York: Russell Sage Foundation, 2006.

Blanden, J. and Machin, M.. (2004). "Educational inequality and the expansion of UK higher education.” Scottish Journal of Political Economy, 51: 230-249.

Bonke, J. and Browning, M. (2011), "Spending on Children: Direct Survey Evidence”. The Economic Journal, 121: F123-F143. doi: 10.1111/j.1468-0297.2011.02444.x.

Bound, J., Hershbein, B. and Long, B. T. (2009). "Playing the Admissions Game: Student Reactions to Increasing College Competition." Journal of Economic Perspectives 23(4):119-46.

Chevalier, A. and Conlon. G. (2003). “Does it pay to attend a prestigious university?” London School of Economics, CEE, DP 33

Chevalier, A.. (2014). "Does Higher Education Quality Matter in the UK?,"IZA Discussion Papers 8363.

Chowdry, H., Crawford, C., Dearden, L., Goodman, A. and Vignoles, A. (2013). "Widening participation in higher education: analysis using linked administrative data”. Journal of the Royal Statistical Society: Series A (Statistics in Society), 176: 431-457.

Coe, R \& Tymms, P. (2008). "Summary of research on changes in educational standards in the UK.” In M. Harris, Educational Briefing Book 2008: IoD Policy Paper. London: Institute of Directors.

Dearden, L., Fitzsimons, E., Goodman, A. and Kaplan, G. (2008). "Higher Education Funding Reforms in England: The Distributional Effects and the Shifting Balance of Costs”. The 
Economic Journal, 118: F100-F125. doi: 10.1111/j.1468-0297.2007.02118.x

Dearden, L., Fitzsimons, R. and Wyness, G. (2011). "The Impact of Tuition Fees and Support on University Participation in the UK," CEE Discussion Papers 0126, Centre for the Economics of Education, LSE.

Del Boca, D., Flinn, C. and Wiswall, M. (2014). "Household Choices and Child Development". Review of Economic Studies. 81, 137-185.

Doepke, M. and Zilibotti, M. (2014). "Parenting with Style: Altruism and Paternalism in Intergenerational Preference Transmission," NBER Working Papers 20214.

European Values Study 1981-2008, Longitudinal Data File. GESIS Data Archive, Cologne, ZA4804 Data File Version 2.0.0, doi:10.4232/1.11005

Ermisch, J., Jantti, M. and Smeeding, T. (2012). (eds.) From parents to children: the intergenerational transmission of advantage. Russell Sage Foundation, New York, N.Y. ISBN 978-0-87154-045-4.

Epple, D., Romano, R., Sarpça, S. and Sieg, H. (2006). "Profiling in Bargaining Over College Tuition”. The Economic Journal, 116: F459-F479. doi: 10.1111/j.1468-0297.2006.01132.x.

Evans, P. (1998). "Why has the female unemployment rate fallen so much in Britain?," Bank of England working papers 87, Bank of England.

Fiorini, M. and Keane, M. P. (2014). “How the Allocation of Children's Time Affects Cognitive and Noncognitive Development." Journal of Labor Economics 32(4), 787 - 836.

Fisher, K. and Gershuny, J. (2013). Multinational Time Use Study User's Guide and Documentation. Oxford, UK: Centre for Time Use Research, University of Oxford.

Gatenby, R. (2003). Comparison of Time Use Data from Pre-Coded Diaries and Fully-Written Diaries. London, UK: Office for National Statistics. http://www.timeuse.org/sites/ctur/files/public/ctur_report/4965/gatenby_2003_light_vs_heavy.p $\underline{\mathrm{df}}$

Gershuny, J. and Smith, R. (1995). Report to the Central Statistical Office on the development of a simple diary schedule October 1995. OPCS Omnibus: review of the first six months, London: OPCS.

Gibbons, S. and Vignoles, A. (2009). "Access, Choice and Participation in Higher Education," CEE Discussion Papers 0101, Centre for the Economics of Education, LSE.

Gimenez-Nadal, J.I. and Sevilla, A. (2012). "Trends in time allocation: A cross-country analysis," European Economic Review, 56(6): 1338-1359.

Goldin, C. (2006). "The Quiet Revolution That Transformed Women's Employment, Education, and Family," American Economic Review, 96(2): 1-21.

Green, F., Machin, S., Murphy, R. and Zhu, Y. (2012), The Changing Economic Advantage from Private Schools. Economica, 79: 658-679. doi: 10.1111/j.1468-0335.2011.00908.x 
Greenaway, D. and Haynes, M. (2003). "Funding Higher Education in The UK: The Role of Fees and Loans," Economic Journal 113(485) F150-F166.

Guryan, J., Hurst, E. and Kearney, M. (2008). "Parental Education and Parental Time With Children,” Journal of Economic Perspectives, Summer 2008: 23-46.

Heckman, J. and Cunha, F. (2007). "The Technology of Skill Formation." American Economic Review 97(2):31-47.

HEFCE. (2001a). Supply and demand in higher education, HEFCE Consultation 01/62.http://webarchive.nationalarchives.gov.uk/20100202100434/http://www.hefce.ac.uk/pubs /hefce/2001/01_62.htm

Higher Education Statistics Agency. (1994-2005). Students in Higher Education Institutions. London, UK: Higher Education Statistics Agency. https://www.hesa.ac.uk/pubs/students

Hoare, T. (1991). "University competition, student migration and regional economic differentials in the United Kingdom”. Higher Education 22: 351-370.

Hoxby, C. M. (2009). “The Changing Selectivity of American Colleges”. Journal of Economic Perspectives, 23(4), 95-118.

Hussain, I., McNally, S. and Telhaj, S. (2009)."University Quality and Graduate Wages in the UK,"IZA Discussion Papers 4043.

Jerrim, J., Vignoles, A. and Finnie. R. (2012). "University access for disadvantaged children: A comparison across English speaking countries." DoQSS Working Papers 12-11, University of London.

Lareau, A. (2003). Unequal Childhoods, Berkeley: University of California Press, 2003.

Leaker, D. (2009). “Unemployment trends since the 1970s” Economic \& Labour Market Review 3(2), 37-41.

Machin, S. and Vignoles, A. (2004). "Educational inequality: the widening socio-economic gap," Fiscal Studies, 25(2): 107-128.

McClelland, R. J. and Gandy, R. J. (2012). "Undergraduate regional migration in the UK: perspectives on local markets and trends for gender and international student groups.” Studies in Higher Education 37(8): 901-924.

Moav, O. (2005). "Cheap Children and the Persistence of Poverty," Economic Journal, 115(500): 88-110.

OECD. (2012). Education at a Glance 2011: OECD Indicators. http://www.oecd.org/education/school/educationataglance2011oecdindicators.htm

Putnam, R. D. (2015). Our Kids: The American Dream in Crisis. New York: Simon and Schuster.

Ramey, G. and Ramey, V. A. (2010). “The Rug Rat Race”, Brookings Papers on Economic Activity. Spring 129-176.

Reay, D. (2005). “Doing the dirty work of social class? Mothers' work in support of their 
children's schooling.” The Sociological Review, 53: 104-116.

Sayer, L. and Gornick, J. (2012). "Cross-National Variation in the Influence of Employment Hours on Child Care Time.” European Sociological Review. 28 (4): 421-442.

Sayer, L, Bianchi, S. and Robinson, J. (2004a), "Are parents investing less in children? Trends in mothers' and fathers' time with children” American Journal of Sociology, 10(1): 1-43.

Sayer, L., Gauthier, A. and Furstenberg, F. (2004b). "Educational differences in parents' time with children: Cross-national variations” Journal of Marriage and the Family, 66(5): 1149-1166.

Sullivan, O. (2010). "Changing Differences by Educational Attainment in Fathers' Domestic Labour and Child Care”. Sociology 44(4): 716-733.

Universities Statistical Record, Universities' Statistical Record, (1972/73-1993/94): Undergraduate Records [computer file]. Colchester, Essex: UK Data Archive [distributor], June 1996. SN: 3456 http://dx.doi.org/10.5255/UKDA-SN-3456-1

van Kesteren, J.N. (1989; 1992; 1996; 2000; 2005). International Crime Victims Surveys - ICVS 1989, 1992, 1996, 2000, 2005 Persistent Identifier: urn:nbn:nl:ui:13-wx0-h0o Data Archiving and Networked Services - DANS.

Walker, I. and Zhu, Y. (2008). "The College Wage Premium and the Expansion of Higher Education in the UK," Scandinavian Journal of Economics, 110(4): 695-709.

Wight, V., Price, J., Bianchi, S. and Hunt, B. (2009). "The Time Use of Teenagers". Social Science Research 38(4), 792-809.

World Value Survey. (1981, 1990, 1995, 2000, 2005). (ICPSR 6160). Ann Arbor, MI: Interuniversity Consortium for Political and Social Research. 
Panel A. Proportion of Students
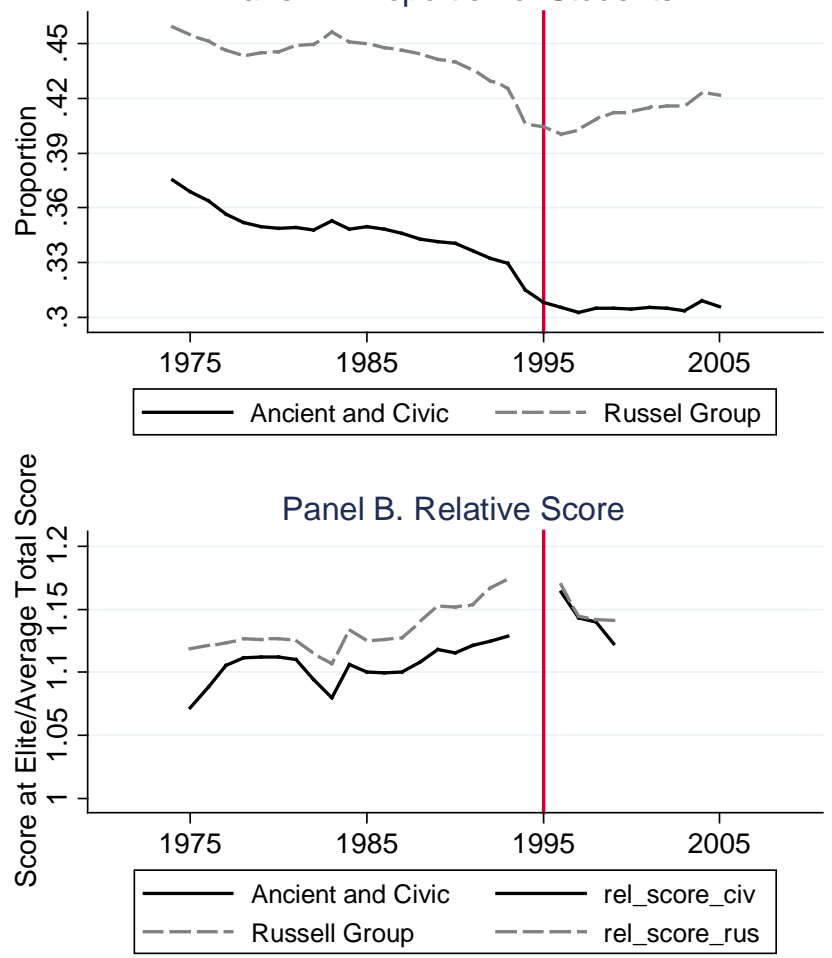

Panel C. Education Gradients

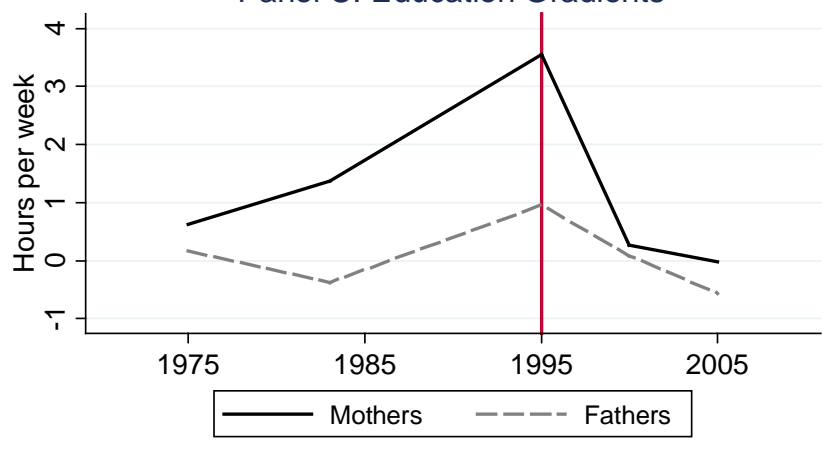

Figure 1. Competition for College Admissions at Elite Universities and Education Gradients in Time Investments

Note: See Appendix for the sample of universities and the categorization of elite universities. Panel A shows the proportion of fulltime undergraduate students enrolled at elite universities out of the total number of students attending existing Higher Education institutions before the passage of the 1992 Further Education Act as offered in Columns 6 and 9 of Table A.10. Panel B shows the ratio of average scores of students enrolled at elite universities to average scores of all students as offered in Columns 5 and 7 of Table A.11. Individual students' scores are calculated summing up scores from their 3 top A-level scores with A's gaining 10 points, B's, 8, C's, 6, D's, 4, and E's, 2 in USR and two points more, from 12 to 4, in THES. Panel C plots the coefficients in Panels B and C of Columns 1 and 3 of Table 1.

Source: MTUS (1974, 1983, 1995, 2000, 2005), University Statistical Records Microdata (1972-1993), Higher Education Statistical Agency (1994-2005) and Times Higher Education Supplement (1996-1999). 
Table 1- Trends in Parental Time Investments by Educational Attainment. UK (1974-2005)

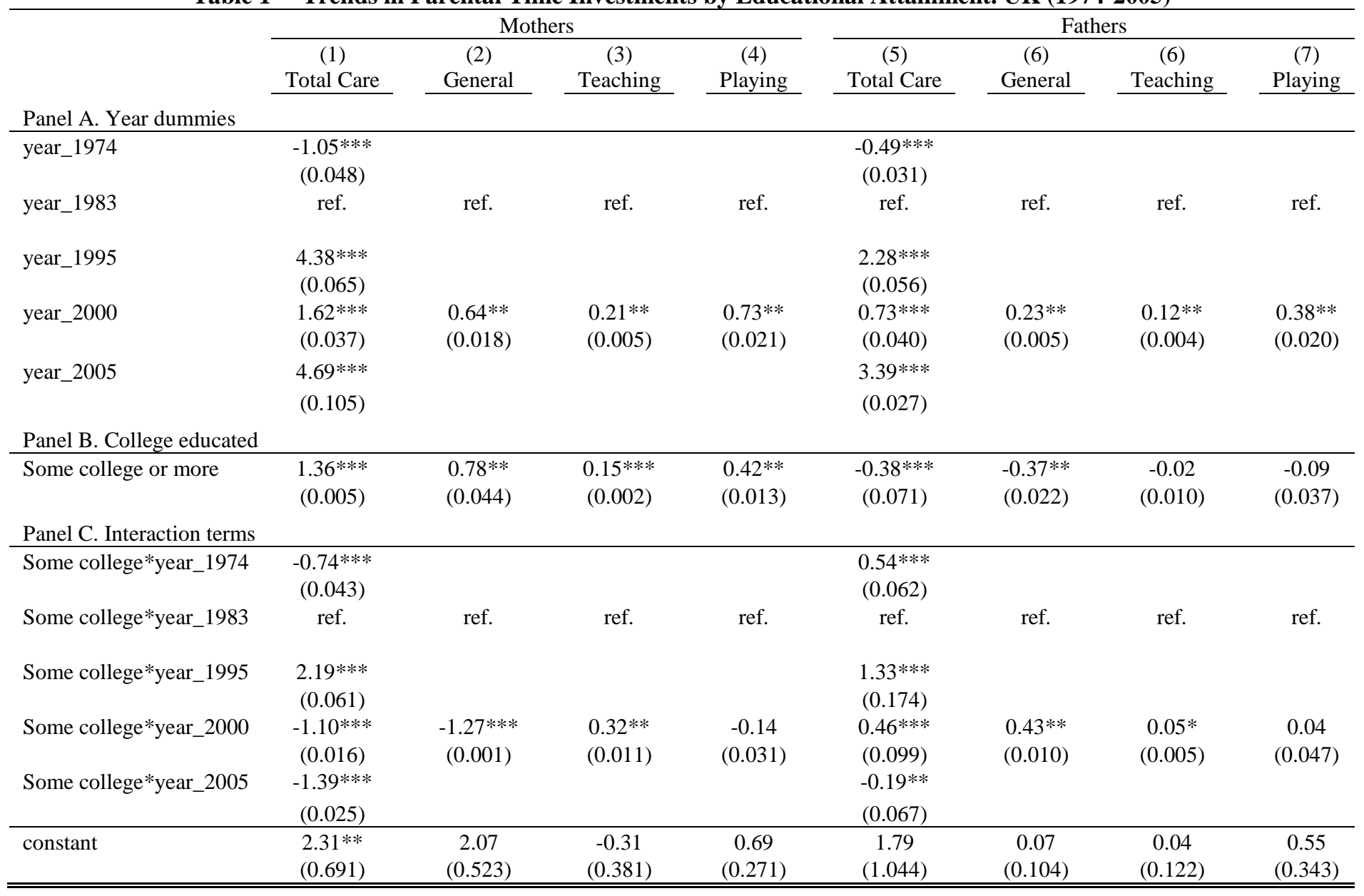

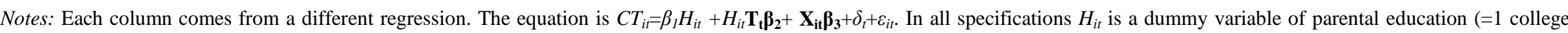

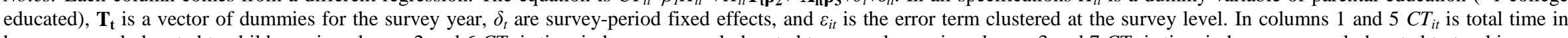

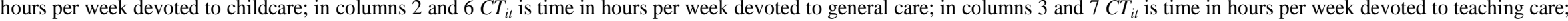

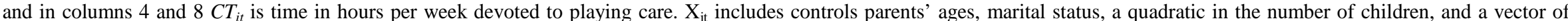

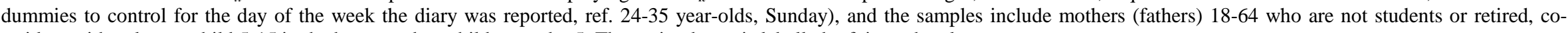
resident with at least a child 5-15 in the house and no children under 5. The omitted year is labelled ref. in each column.

Source:MTUS (1974-2005)

*** Significant at the 1 percent level.

** Significant at the 5 percent level. 
Table 2- Trends in Children's Time Investments by Educational Attainment. US (1985-2008) and UK (1974-2005)

\begin{tabular}{|c|c|c|c|c|c|c|}
\hline & \multicolumn{3}{|c|}{ US } & \multicolumn{3}{|c|}{ UK } \\
\hline & $\begin{array}{c}1) \\
\text { Travel }\end{array}$ & $\begin{array}{c}(2) \\
\text { School }\end{array}$ & $\begin{array}{c}(3) \\
\text { Homework }\end{array}$ & $\begin{array}{c}(4) \\
\text { Travel }\end{array}$ & $\begin{array}{c}(5) \\
\text { School }\end{array}$ & $\begin{array}{c}(6) \\
\text { Homework }\end{array}$ \\
\hline Panel A. College educated & & & & & & \\
\hline Some college or more & $\begin{array}{c}-0.63 \\
(0.119)\end{array}$ & $\begin{array}{l}-4.21 * * \\
(0.226)\end{array}$ & $\begin{array}{l}3.22 * * \\
(0.145)\end{array}$ & $\begin{array}{l}0.56 * * \\
(0.075)\end{array}$ & $\begin{array}{l}4.31^{* *} \\
(0.758)\end{array}$ & $\begin{array}{c}4.25^{* * *} \\
(0.062)\end{array}$ \\
\hline Panel B. Interaction terms & & & & & & \\
\hline Some college*year_1974 & ref. & ref. & ref. & $\begin{array}{c}-0.71 * * \\
(0.112) \\
\text { ref. }\end{array}$ & $\begin{array}{c}6.93^{* *} \\
\text { (0.767) } \\
\text { ref. }\end{array}$ & $\begin{array}{c}-4.21 * * * \\
(0.031) \\
\text { ref. }\end{array}$ \\
\hline Some college*year_2000_08 & $\begin{array}{c}0.70^{*} \\
(0.107)\end{array}$ & $\begin{array}{l}4.04 * * \\
(0.188)\end{array}$ & $\begin{array}{l}-1.89 * \\
(0.249)\end{array}$ & $\begin{array}{c}-0.22 \\
(0.082)\end{array}$ & $\begin{array}{c}-0.10 \\
(0.892) \\
\end{array}$ & $\begin{array}{c}-0.16 \\
(0.056)\end{array}$ \\
\hline
\end{tabular}

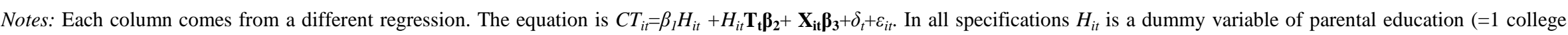

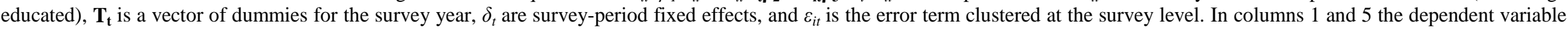

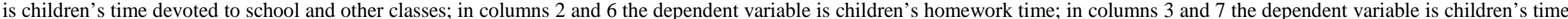

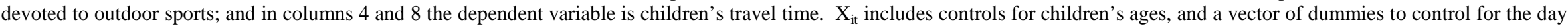
of the week the diary was reported (ref. Sunday). The sample includes all children 14-17years-old. The omitted year is labelled ref. in each column.

Source:MTUS (1974-2005)

*** Significant at the 1 percent level.

** Significant at the 5 percent level. 
Table 3- Trends in College Education Gradients-Robustness Checks

\begin{tabular}{|c|c|c|c|c|c|c|c|c|}
\hline & \multicolumn{2}{|c|}{ Selection into parenthood } & \multicolumn{2}{|c|}{ Income effects } & \multicolumn{2}{|c|}{ Working Arrangements } & \multicolumn{2}{|c|}{ Definition of education } \\
\hline & $\begin{array}{c}(1) \\
\text { Mothers }\end{array}$ & $\begin{array}{c}(2) \\
\text { Fathers }\end{array}$ & $\begin{array}{c}\text { (3) } \\
\text { Mothers }\end{array}$ & $\begin{array}{c}\text { (4) } \\
\text { Fathers }\end{array}$ & $\begin{array}{c}\text { (5) } \\
\text { Working } \\
\end{array}$ & $\begin{array}{c}(6) \\
\text { Non-working }\end{array}$ & $\begin{array}{c}(7) \\
\text { Mothers }\end{array}$ & $\begin{array}{c}(8) \\
\text { Fathers }\end{array}$ \\
\hline Panel A. College educated & & & & & & & & \\
\hline Some college or more & $\begin{array}{c}0.09 \\
(0.091)\end{array}$ & $\begin{array}{c}-0.15^{* * *} \\
(0.017)\end{array}$ & $\begin{array}{l}1.57 * * * \\
(0.069)\end{array}$ & $\begin{array}{l}-0.53^{* *} \\
(0.140)\end{array}$ & $\begin{array}{l}1.42^{* * * *} \\
(0.018)\end{array}$ & $\begin{array}{l}1.84^{* * * *} \\
(0.080)\end{array}$ & $\begin{array}{l}1.09 * * * \\
(0.086)\end{array}$ & $\begin{array}{c}-0.01 \\
(0.081)\end{array}$ \\
\hline Panel B. Interaction terms & & & & & & & & \\
\hline Some college*year_1974 & $\begin{array}{l}0.08^{* *} \\
(0.019)\end{array}$ & $\begin{array}{l}0.27 * * * \\
(0.044)\end{array}$ & $\begin{array}{c}-0.99 * * * \\
(0.126)\end{array}$ & $\begin{array}{c}0.48^{* * *} \\
(0.029)\end{array}$ & $\begin{array}{c}-0.57 * * * \\
(0.051)\end{array}$ & $\begin{array}{l}-2.17 * * \\
(0.280)\end{array}$ & $\begin{array}{c}-0.88 * * * \\
(0.023)\end{array}$ & $\begin{array}{l}0.36 * * \\
(0.098)\end{array}$ \\
\hline Some college*year_1983 & ref. & ref. & ref. & ref. & ref. & ref. & ref. & ref. \\
\hline Some college*year_1995 & $\begin{array}{c}0.23 * * * \\
(0.021)\end{array}$ & $\begin{array}{l}0.16^{* *} \\
(0.040)\end{array}$ & $\begin{array}{c}2.32 * * * \\
(0.100)\end{array}$ & $\begin{array}{l}1.24 * * * \\
(0.199)\end{array}$ & & & $\begin{array}{c}2.46 * * * \\
(0.132)\end{array}$ & $\begin{array}{c}0.97 * * * \\
(0.141)\end{array}$ \\
\hline Some college*year_2000 & $\begin{array}{c}-0.31^{* * *} \\
(0.044)\end{array}$ & $\begin{array}{c}-0.06 * * * \\
(0.012)\end{array}$ & $\begin{array}{c}-1.22 * * * \\
(0.092)\end{array}$ & $\begin{array}{c}0.37^{*} \\
(0.128)\end{array}$ & $\begin{array}{c}-0.73 * * * \\
(0.008)\end{array}$ & $\begin{array}{c}-1.48 * * * \\
(0.084)\end{array}$ & $\begin{array}{c}-0.83 * * * \\
(0.075)\end{array}$ & $\begin{array}{c}0.10 \\
(0.089)\end{array}$ \\
\hline Some college*year_2005 & $\begin{array}{c}-1.01^{* * *} \\
(0.030) \\
\end{array}$ & $\begin{array}{c}-0.77 * * * \\
(0.019) \\
\end{array}$ & & & & & $\begin{array}{c}-1.12^{* * *} \\
(0.087) \\
\end{array}$ & $\begin{array}{r}-0.55^{* * *} \\
(0.106) \\
\end{array}$ \\
\hline Income 2 & & & $\begin{array}{c}-1.07 \\
(0.520)\end{array}$ & $\begin{array}{c}0.04 \\
(0.132)\end{array}$ & & & & \\
\hline Income 3 & & & $\begin{array}{c}-0.56 \\
(0.598)\end{array}$ & $\begin{array}{c}0.42 \\
(0.239) \\
\end{array}$ & & & & \\
\hline constant & $\begin{array}{c}1.11 * \\
(0.441)\end{array}$ & $\begin{array}{c}0.19 \\
(0.186)\end{array}$ & $\begin{array}{c}3.19 * * * \\
(0.352)\end{array}$ & $\begin{array}{c}1.44 \\
(0.990)\end{array}$ & $\begin{array}{c}2.98 * * * \\
(0.122)\end{array}$ & $\begin{array}{c}1.51 \\
(0.805)\end{array}$ & $\begin{array}{l}2.30 * * \\
(0.693)\end{array}$ & $\begin{array}{c}1.74 \\
(1.026)\end{array}$ \\
\hline
\end{tabular}

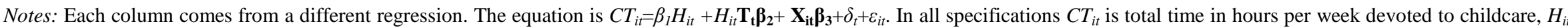

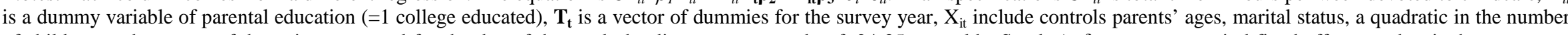

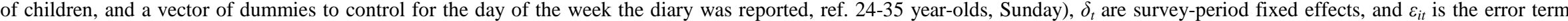

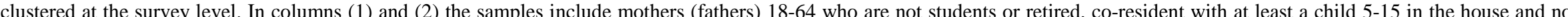

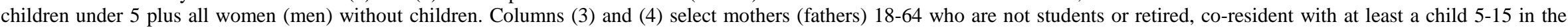

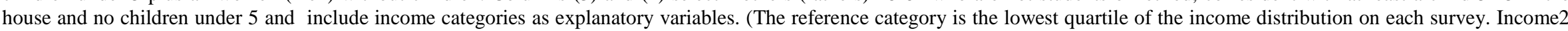

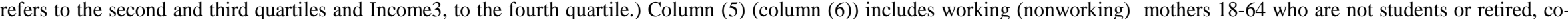

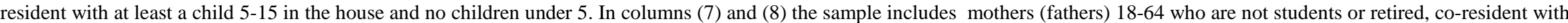

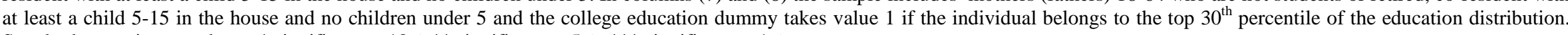
Standard errors in parentheses.* significant at $10 \%$ ** significant at 5\%; *** significant at $1 \%$.

Source: MTUS (1974-2005) 
Table 4- Trends in Women and Men's Safety Fears by Educational Attainment

\begin{tabular}{|c|c|c|c|c|}
\hline \multirow[b]{4}{*}{ Panel A. Year dummies } & \multicolumn{2}{|c|}{ Female } & \multicolumn{2}{|c|}{ Male } \\
\hline & \multirow{2}{*}{$\begin{array}{c}\text { (1) } \\
\text { Likelihood of burglary }\end{array}$} & \multirow{2}{*}{$\begin{array}{c}\text { (2) } \\
\text { Feelings of unsafety }\end{array}$} & \multirow{2}{*}{$\begin{array}{c}\text { (3) } \\
\text { Likelihood of burglary }\end{array}$} & \multirow{3}{*}{$\begin{array}{l}\text { (4) } \\
\text { Feelings of unsafety }\end{array}$} \\
\hline & & & & \\
\hline & & & & \\
\hline year_1989 & ref. & & ref. & \\
\hline \multirow[t]{2}{*}{ year_1996 } & $0.09 * * *$ & ref. & $0.02 * *$ & ref. \\
\hline & $(0.003)$ & & $(0.007)$ & \\
\hline \multirow[t]{2}{*}{ year_2000 } & $0.02 * * *$ & $-0.03 * * *$ & $-0.02 *$ & $-0.02 * * *$ \\
\hline & $(0.002)$ & $(0.002)$ & $(0.006)$ & $(0.001)$ \\
\hline \multirow[t]{2}{*}{ year_2004_5 } & $0.09 * * *$ & $0.02 * * *$ & -0.01 & $0.04 * * *$ \\
\hline & $(0.002)$ & $(0.001)$ & $(0.007)$ & $(0.000)$ \\
\hline \multicolumn{5}{|c|}{ Panel B. College educated } \\
\hline \multirow[t]{2}{*}{ Some college or more } & $0.02 * * *$ & $-0.06^{* * *}$ & $0.01 *$ & $-0.02 * * *$ \\
\hline & $(0.002)$ & $(0.001)$ & $(0.003)$ & $(0.001)$ \\
\hline \multicolumn{5}{|c|}{ Panel C. Interaction terms } \\
\hline Some college*1989 & ref. & & ref. & \\
\hline \multirow[t]{2}{*}{ Some college*1996 } & $-0.04 * * *$ & ref. & $-0.07 * * *$ & ref. \\
\hline & $(0.001)$ & & $(0.002)$ & \\
\hline \multirow[t]{2}{*}{ Some college*2000 } & $-0.05^{* * *}$ & $0.03 * * *$ & $-0.03^{* * *}$ & $0.01 *$ \\
\hline & $(0.001)$ & $(0.002)$ & $(0.001)$ & $(0.002)$ \\
\hline \multirow[t]{2}{*}{ Some college*2004_5 } & $-0.10 * * *$ & -0.00 & $-0.04 * * *$ & $-0.05 * * *$ \\
\hline & $(0.002)$ & $(0.002)$ & $(0.004)$ & $(0.002)$ \\
\hline \multirow[t]{2}{*}{ Constant } & $0.08 * * *$ & $0.15^{* *}$ & $0.06^{* * *}$ & $0.04 * * *$ \\
\hline & $(0.005)$ & $(0.027)$ & $(0.010)$ & $(0.003)$ \\
\hline
\end{tabular}

Notes: Each column comes from a different regression. The equation is $Y_{i t}=\beta_{1} H_{i t}+H_{i t} \mathbf{T}_{\mathbf{t}} \boldsymbol{\beta}_{2}+\mathbf{X}_{\mathbf{i t}} \boldsymbol{\beta}_{3}+\delta_{t}+\varepsilon_{i t}$. In all specifications $H_{i t}$ is a dummy variable of educational attainment (=1 college educated), $\mathbf{T}_{\mathbf{t}}$ is a vector of dummies for the survey year, $\mathrm{X}_{\mathrm{it}}$ include controls for individuals' ages and marital status (ref. 24-35 year-olds), $\delta_{t}$ are survey-period fixed effects, and $\varepsilon_{i t}$ is the error term clustered at the survey level. In columns (1) and (3) $Y_{i t}$ is the likelihood of respondents' house being burgled in the coming year (1=very likely) and in columns (2) and (4) $Y_{i t}$ is an indicator of whether they feel unsafe when walking alone in their area after dark (1=very unsafe). The samples include all women (men) 18-64 who are not students or retired (no information on number of children for 2005 but results similar when selecting parents). Standard errors in parentheses. * significant at $10 \% * *$ significant at $5 \%$; *** significant at $1 \%$.

Source: International Crime Victims Survey Data, 1989-2005. 
Table 5- Trends in Parenting Values by Educational Attainment

\begin{tabular}{|c|c|c|}
\hline & $\begin{array}{c}(1) \\
\text { Female }\end{array}$ & $\begin{array}{c}(2) \\
\text { Male } \\
\end{array}$ \\
\hline \multicolumn{3}{|l|}{ Panel A. Year dummies } \\
\hline year_1981 & ref. & ref. \\
\hline year_1990 & $\begin{array}{c}0.40^{* * *} \\
(0.008)\end{array}$ & $\begin{array}{c}0.41 * * * \\
(0.008)\end{array}$ \\
\hline year_1999 & $\begin{array}{c}0.61 * * * \\
(0.005)\end{array}$ & $\begin{array}{c}0.85^{* * *} \\
(0.012)\end{array}$ \\
\hline year_2005 & $\begin{array}{c}0.72 * * * \\
(0.020)\end{array}$ & $\begin{array}{c}1.04 * * * \\
(0.014)\end{array}$ \\
\hline \multicolumn{3}{|l|}{ Panel B. College educated } \\
\hline Some college or more & $\begin{array}{c}0.11^{* * *} \\
(0.009)\end{array}$ & $\begin{array}{c}0.60 * * * \\
(0.005)\end{array}$ \\
\hline \multicolumn{3}{|l|}{ Panel C. Interaction terms } \\
\hline Some college*1981 & ref. & ref. \\
\hline Some college*1990 & $\begin{array}{c}0.13 * * * \\
(0.007)\end{array}$ & $\begin{array}{c}-0.27 * * * \\
(0.010)\end{array}$ \\
\hline Some college*1999 & $\begin{array}{c}0.13^{* * *} \\
(0.008)\end{array}$ & $\begin{array}{c}-0.55^{* * *} \\
(0.008)\end{array}$ \\
\hline Some college*2005 & $\begin{array}{c}0.10^{* * *} \\
(0.012)\end{array}$ & $\begin{array}{c}-0.59 * * * \\
(0.011) \\
\end{array}$ \\
\hline Constant & $\begin{array}{c}-0.37 * * * \\
(0.020)\end{array}$ & $\begin{array}{c}-0.60 * * * \\
(0.059)\end{array}$ \\
\hline
\end{tabular}

Notes: Each column comes from a different regression. The equation is $Y_{i t}=\beta_{1} H_{i t}+H_{i t} \mathbf{T}_{\mathbf{t}} \boldsymbol{\beta}_{\mathbf{2}}+\mathbf{X}_{\mathbf{i t}} \boldsymbol{\beta}_{3}+\delta_{t}+\varepsilon_{i t}$. In all specifications $H_{i t}$ is a dummy variable of parental education (=1 college educated), $\mathbf{T}_{\mathbf{t}}$ is a vector of dummies for the survey year, $\mathrm{X}_{\mathrm{it}}$ include controls for parents' ages and marital status (ref. 24-35 year-olds), $\delta_{t}$ are survey-period fixed effects, and $\varepsilon_{i t}$ is the error term clustered at the survey level. The dependent variable $Y_{i t}$ is a composite measure of child-rearing values computed applying principal component analysis to the respondents' rankings on the qualities that children can be encouraged to learn at home from the following list: independence; hard work; feeling of responsibility; tolerance and respect; thrift, saving money and things; determination, perseverance; religious faith; and obedience. The samples include all mothers (fathers) 18-64 who are not students or retired. Standard errors in parentheses. * significant at $10 \% * *$ significant at $5 \%$; *** significant at $1 \%$.

Source: European Values Study (1981, 1990, and 1999) and World Values Survey Data, 2005. 
Table 6- Trends in Parental Time Investments by Educational Attainment and Region. UK (1974-2005)

\begin{tabular}{|c|c|c|c|c|c|c|c|c|}
\hline & \multicolumn{4}{|c|}{ Mothers } & \multicolumn{4}{|c|}{ Fathers } \\
\hline & $\begin{array}{c}(1) \\
\text { Oxbridge } \\
\text { Regions } \\
\end{array}$ & $\begin{array}{c}(2) \\
\text { Non-oxbridge } \\
\text { Regions } \\
\end{array}$ & $\begin{array}{c}\text { (3) } \\
\text { Civic } \\
\text { Regions } \\
\end{array}$ & $\begin{array}{c}(4) \\
\text { Non-civic } \\
\text { Regions } \\
\end{array}$ & $\begin{array}{l}(5) \\
\text { Oxbridge } \\
\text { Regions } \\
\end{array}$ & $\begin{array}{c}(6) \\
\text { Non-oxbridge } \\
\text { Regions } \\
\end{array}$ & $\begin{array}{c}\text { (7) } \\
\text { Civic } \\
\text { Regions } \\
\end{array}$ & $\begin{array}{c}(8) \\
\text { Non-civic } \\
\text { Regions } \\
\end{array}$ \\
\hline \multicolumn{9}{|l|}{ Panel A. Year dummies } \\
\hline $\begin{array}{l}\text { year_1974 } \\
\text { year_1983 }\end{array}$ & $\begin{array}{l}-0.40^{*} \\
(0.145) \\
\text { ref. }\end{array}$ & $\begin{array}{l}-0.95 * * * \\
(0.067) \\
\text { ref. }\end{array}$ & $\begin{array}{l}-0.40 * * * \\
(0.077) \\
\text { ref. }\end{array}$ & $\begin{array}{l}-1.57 * * * \\
(0.059) \\
\text { ref. }\end{array}$ & $\begin{array}{l}-0.10 \\
(0.062) \\
\text { ref. }\end{array}$ & $\begin{array}{l}-0.54 * * * \\
(0.026) \\
\text { ref. }\end{array}$ & $\begin{array}{l}-0.40 * * * \\
(0.015) \\
\text { ref. }\end{array}$ & $\begin{array}{c}-0.49 * * * \\
(0.076) \\
\text { ref. }\end{array}$ \\
\hline year_1995 & $\begin{array}{c}3.96 * * * \\
(0.045)\end{array}$ & $\begin{array}{c}5.03^{* * *} \\
(0.032)\end{array}$ & $\begin{array}{c}5.00 * * * \\
(0.051)\end{array}$ & $\begin{array}{c}3.77 * * * \\
(0.087)\end{array}$ & $\begin{array}{c}-0.57 * * \\
(0.157)\end{array}$ & $\begin{array}{c}3.83 * * * \\
(0.075)\end{array}$ & $\begin{array}{c}0.58^{* * *} \\
(0.028)\end{array}$ & $\begin{array}{c}5.88^{* * *} \\
(0.219)\end{array}$ \\
\hline year_2000 & $\begin{array}{c}1.63 * * * \\
(0.138)\end{array}$ & $\begin{array}{c}1.77 * * * \\
(0.064)\end{array}$ & $\begin{array}{c}1.82 * * * \\
(0.059)\end{array}$ & $\begin{array}{c}1.44 * * * \\
(0.097)\end{array}$ & $\begin{array}{c}0.97 * * * \\
(0.044)\end{array}$ & $\begin{array}{c}0.52 * * * \\
(0.061)\end{array}$ & $\begin{array}{c}0.89 * * * \\
(0.017)\end{array}$ & $\begin{array}{c}0.09 \\
(0.205)\end{array}$ \\
\hline year_2005 & $\begin{array}{l}5.25^{* * *} \\
(0.083)\end{array}$ & $\begin{array}{c}4.98^{* * *} \\
(0.073)\end{array}$ & $\begin{array}{c}4.75^{* * *} \\
(0.099)\end{array}$ & $\begin{array}{c}5.55^{* * *} \\
(0.097)\end{array}$ & $\begin{array}{c}5.62 * * * \\
(0.046)\end{array}$ & $\begin{array}{c}2.60^{* * *} \\
(0.068)\end{array}$ & $\begin{array}{c}3.62 * * * \\
(0.049)\end{array}$ & $\begin{array}{c}3.16^{* * *} \\
(0.079)\end{array}$ \\
\hline \multicolumn{9}{|l|}{ Panel B. College educated } \\
\hline Some college or more & $\begin{array}{l}1.72 * * * \\
(0.122)\end{array}$ & $\begin{array}{c}1.04 * * * \\
(0.032)\end{array}$ & $\begin{array}{c}1.79 * * * \\
(0.048)\end{array}$ & $\begin{array}{c}-1.33 * * * \\
(0.247)\end{array}$ & $\begin{array}{c}-0.49 * * \\
(0.160)\end{array}$ & $\begin{array}{c}-0.37 * * * \\
(0.035)\end{array}$ & $\begin{array}{c}-0.26^{* * *} \\
(0.032)\end{array}$ & $\begin{array}{c}-0.72 * * * \\
(0.093)\end{array}$ \\
\hline \multicolumn{9}{|l|}{ Panel C. Interaction terms } \\
\hline $\begin{array}{l}\text { Some college*year_1974 } \\
\text { Some college*year_1983 }\end{array}$ & $\begin{array}{c}-2.96 * * * \\
(0.206) \\
\text { ref. }\end{array}$ & $\begin{array}{l}0.84 * * * \\
(0.112) \\
\text { ref. }\end{array}$ & $\begin{array}{l}-1.45^{* * *} \\
(0.037) \\
\text { ref. }\end{array}$ & $\begin{array}{c}2.45^{* * * *} \\
(0.145) \\
\text { ref. }\end{array}$ & $\begin{array}{l}-0.11 \\
(0.133) \\
\text { ref. }\end{array}$ & $\begin{array}{l}0.94 * * * \\
(0.118) \\
\text { ref. }\end{array}$ & $\begin{array}{c}0.53^{* * *} \\
(0.064)\end{array}$ & $\begin{array}{c}0.57 * * * \\
(0.108)\end{array}$ \\
\hline Some college*year_1995 & $\begin{array}{c}8.68 * * * \\
(0.150)\end{array}$ & $\begin{array}{c}-0.61 * * * \\
(0.089)\end{array}$ & $\begin{array}{c}3.39 * * * \\
(0.193)\end{array}$ & $\begin{array}{c}0.99 \\
(0.491)\end{array}$ & $\begin{array}{c}6.62 * * * \\
(0.220)\end{array}$ & $\begin{array}{c}-1.63 * * * \\
(0.152)\end{array}$ & $\begin{array}{c}2.20^{* * *} \\
(0.088)\end{array}$ & $\begin{array}{c}0.51 \\
(0.358)\end{array}$ \\
\hline Some college*year_2000 & $\begin{array}{c}-1.92 * * * \\
(0.083)\end{array}$ & $\begin{array}{c}-1.13^{* * *} \\
(0.044)\end{array}$ & $\begin{array}{c}-2.17 * * * \\
(0.015)\end{array}$ & $\begin{array}{c}1.93 * * * \\
(0.292)\end{array}$ & $\begin{array}{l}0.48^{* *} \\
(0.134)\end{array}$ & $\begin{array}{c}0.78^{* * *} \\
(0.061)\end{array}$ & $\begin{array}{c}0.00 \\
(0.037)\end{array}$ & $\begin{array}{c}2.77 * * * \\
(0.184)\end{array}$ \\
\hline Some college*year_2005 & $\begin{array}{c}-1.99 * * * \\
(0.129) \\
\end{array}$ & $\begin{array}{c}-1.00^{* * *} \\
(0.086) \\
\end{array}$ & $\begin{array}{c}-1.40 * * * \\
(0.078) \\
\end{array}$ & $\begin{array}{c}0.37 \\
(0.207) \\
\end{array}$ & $\begin{array}{c}-2.45^{* * *} \\
(0.132) \\
\end{array}$ & $\begin{array}{c}0.89 * * * \\
(0.036) \\
\end{array}$ & $\begin{array}{c}-0.66^{* * *} \\
(0.029) \\
\end{array}$ & $\begin{array}{c}0.84 * * \\
(0.196) \\
\end{array}$ \\
\hline constant & $\begin{array}{l}3.30 * * \\
(0.914) \\
\end{array}$ & $\begin{array}{c}2.06 \\
(0.990) \\
\end{array}$ & $\begin{array}{l}2.68 * * \\
(0.684) \\
\end{array}$ & $\begin{array}{c}1.90 \\
(1.215) \\
\end{array}$ & $\begin{array}{c}1.76^{*} \\
(0.642) \\
\end{array}$ & $\begin{array}{c}1.47 \\
(1.124) \\
\end{array}$ & $\begin{array}{c}0.94 \\
(0.675) \\
\end{array}$ & $\begin{array}{c}3.42 \\
(2.217) \\
\end{array}$ \\
\hline
\end{tabular}

Notes: Each column comes from a different regression. The equation is $C T_{i t}=\beta_{1} H_{i t}+H_{i t} \mathbf{T}_{\mathrm{t}} \boldsymbol{\beta}_{2}+\mathbf{X}_{\mathbf{i t}} \boldsymbol{\beta}_{3}+\delta_{t}+\varepsilon_{i t}$. In all specifications $H_{i t}$ is a dummy variable of parental education (=1 college educated), $\mathbf{T}_{\mathbf{t}}$ is a vector of dummies for the survey year, $\delta_{t}$ are survey-period fixed effects, and $\varepsilon_{i t}$ is the error term clustered at the survey level. $C T_{i t}$ is total time in hours per week devoted to childcare. $X_{\text {it }}$ includes controls parents' ages, marital status, a quadratic in the number of children, and a vector of dummies to control for the day of the week the diary was reported, ref. 24-35 year-olds, Sunday), and the samples include mothers (fathers) 18-64 who are not students or retired, co-resident with at least a child 5-15 in the house and no children under 5. In Columns 1 and 5 the samples includes only parents from East of England and London and South West; in Columns 2 and 6, parents from North of England, English Midlands, South and West of England, Wales, and Scotland. In Columns 3 and 7 the samples include only parents from East of England, London and South West, North of England, and Scotland; in Columns 4 and 8, parents from English Midlands, South and West of England, and Wales. The omitted year is labelled ref. in each column.

Source:MTUS (1974-2005)

*** Significant at the 1 percent level. ** Significant at the 5 percent level. 


\section{Data Appendix}

The Multinational Time Use Study (MTUS) is an ex-post harmonized cross-time cross-national comparative time-use database that aggregates daily activities in 40 time use categories with approximately 30 standardized demographic variables (see Fisher and Gershuny (2013) for a description of the time-use surveys in the MTUS). Issues of comparability across time are particularly important in the 1995 and 2005 light diary surveys. Light diaries are time budget instruments suitable for use as add-on components to other surveys without unduly increasing respondents' burden (Gershuny and Smith 1995). Both the 1995 and the 2005 diaries, together with a pilot 2001 diary, were administered alongside OMNIBUS Studies. In these two cases respondents could only choose among 30 pre-coded activities, unlike the 1974, 1983, and 2000 surveys where responses were freely indicated by respondents and then coded by the research teams. Gatenby (2003) assessed the UK light diary methodology by comparing the full scale 2000 time use survey to a 2001 light diary survey, and obtained comparable results for the main categories of activity, including childcare. Furthermore, our analysis comparing parental time investments between educational groups over time should reflect changes in actual behaviour rather than changes in survey methodology, as there is no reason to believe that college and non-college educated parents are affected by data collection methods in systematically different ways (Guryan et al 2008). Moreover, even if survey design affected educational groups differently, both the 1995 and 2005 would face similar biases. But education gradients in parental time investments do not show a common bias for the 1995 and 2005 surveys. 


\section{Appendix Figures}
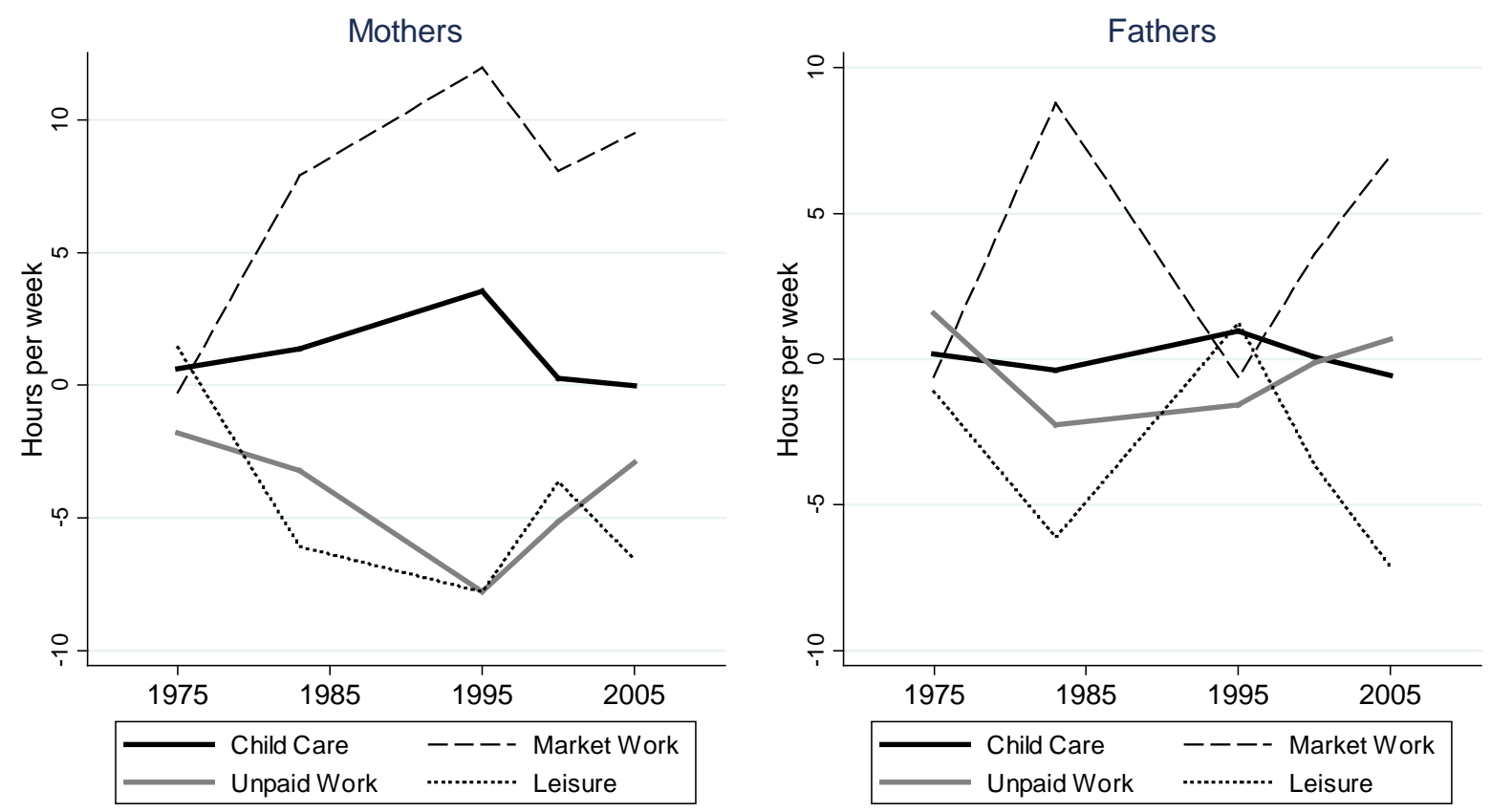

Figure A.1. Trends in Overall Time Use by Parents by Educational Attainment.

Notes: The graphs in this Figure plot the estimated coefficients $\beta_{1}$ and $\boldsymbol{\beta}_{2}$ in the equation $Y_{i t}=\beta_{1} H_{i t}+H_{i t} \mathbf{T}_{\mathbf{t}} \boldsymbol{\beta}_{2}+\mathbf{X}_{\mathbf{i t}} \boldsymbol{\beta}_{3}+\delta_{t}+\varepsilon_{i t}$. The dependent variable $Y_{i t}$ is hours per week spent on market work, unpaid work, leisure and personal care and total childcare. Market work includes all paid work and related commuting, unpaid work comprises housework, food preparation, shopping, and domestic travel, and leisure and personal care consists of any other uses of time, not previously included. In all specifications $H_{i t}$ is a dummy variable of parental education (=1 college educated), $\mathbf{T}_{\mathbf{t}}$ is a vector of dummies for the survey year, $\delta_{t}$ are survey-period fixed effects, $\mathrm{X}_{\mathrm{it}}$ include controls parents' ages, marital status, a quadratic in the number of children, and a vector of dummies to control for the day of the week the diary was reported, ref. 24-35 year-olds, Sunday), and $\varepsilon_{i t}$ is the error term clustered at the survey level. The samples include all mothers (fathers) 18-64 who are not students or retired, where mother is defined as having a child under the age of 18 in the house.

Source: MTUS (1974-2005) 


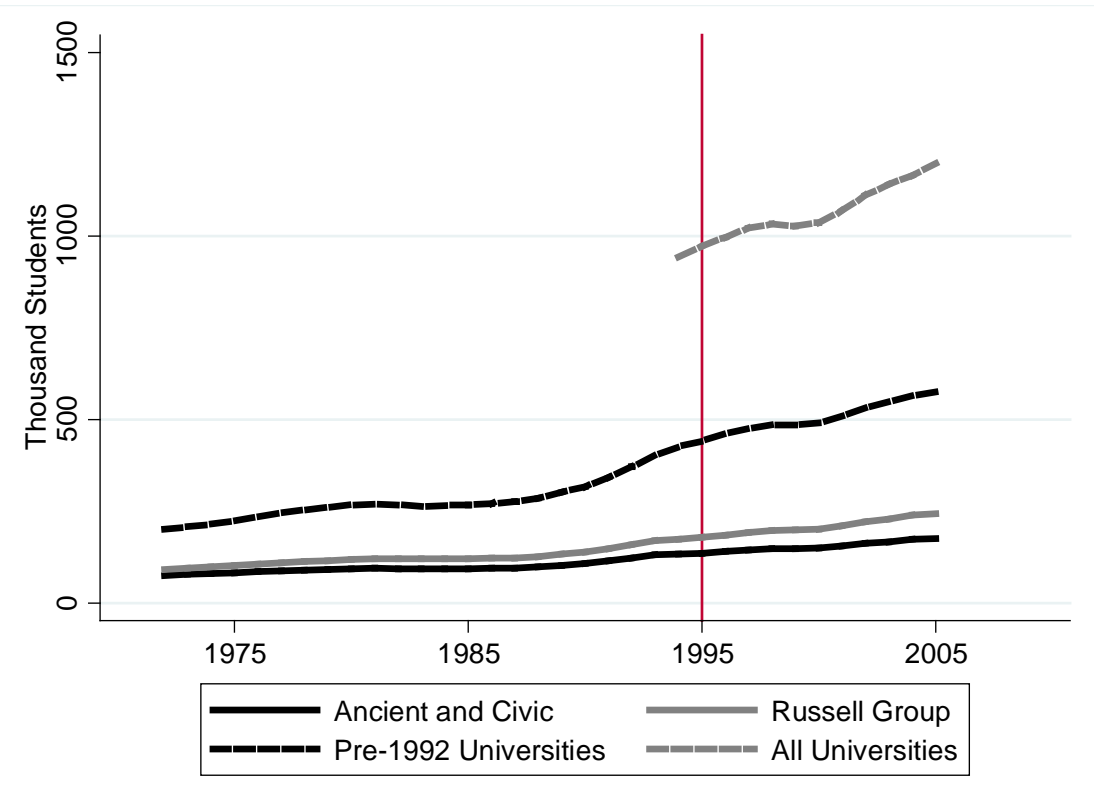

Figure A.2. Enrolment at Different Types Higher Education Institutions

Note: The figure shows total full-time undergraduate students enrolled at elite and non-elite universities as offered in Columns 1, 2, 5, and 8 of Table A.8. Ancient and civic Universities are Oxford, Cambridge, St. Andrews, Glasgow, Aberdeen, and Edinburgh, all founded in the Middle Ages, and Birmingham, Liverpool, Manchester, Leeds, Sheffield, and Bristol, founded in the major industrial cities of England before World War I. The 17 founding members of the Russell Group in 1994 are Birmingham, Bristol, Cambridge, Edinburgh, Glasgow, Imperial College London, Leeds, Liverpool, London School of Economics, Manchester, Newcastle, Nottingham, Oxford, Sheffield, Southampton, University College London, and Warwick. Pre-1992 universities exclude those polytechnics granted university status by the 1992 Further and Higher Education Act and any university founded afterwards.

Source: University Statistical Records Microdata (1972-1993) and Higher Education Statistical Agency (1994-2005). 

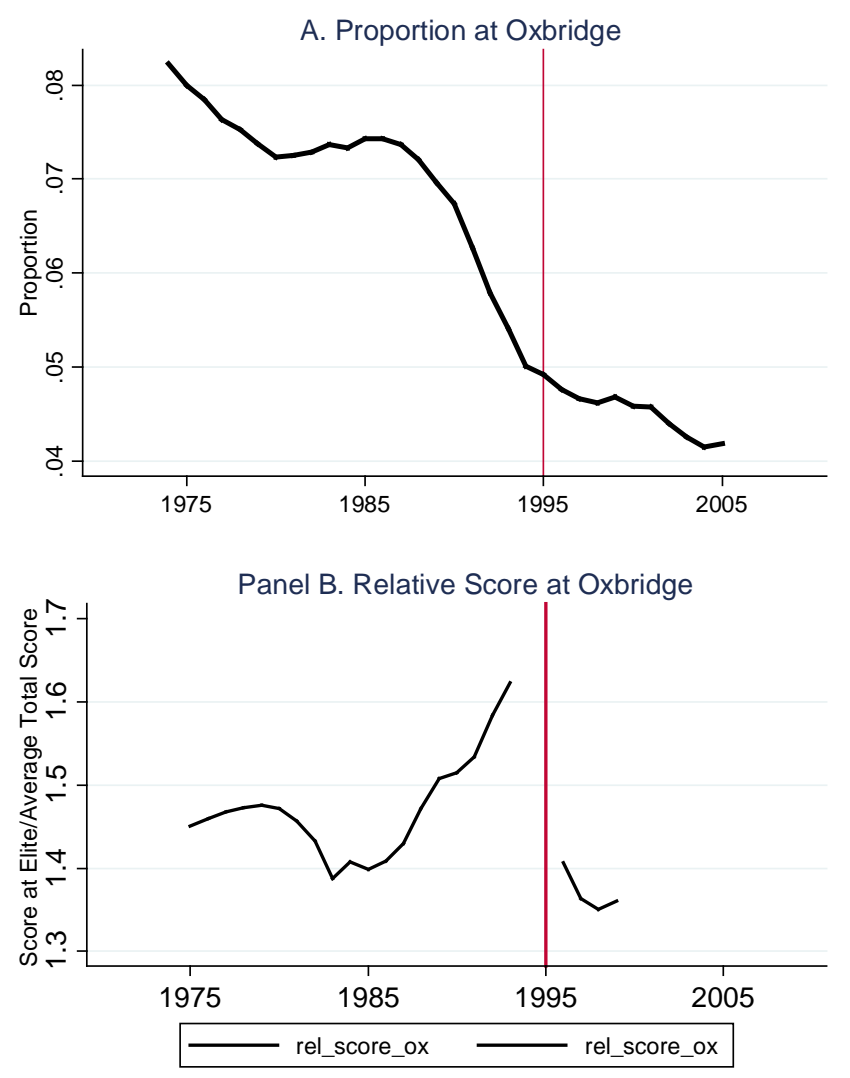

Figure A.3. Competition for College Admissions at Oxbridge

Note: Oxbridge stands for Oxford and Cambridge Universities. Panel A show the proportion of full-time undergraduate students enrolled at elite universities out of the total number of students attending existing Higher Education institutions before the passage of the 1992 Further Education Act that granted university status to previous further education institutions. Panel B show the ratio of average scores of students enrolled at elite universities to average scores of all students. In Panel B the sample includes students with A-level as main entry qualifications. Individual students' scores are calculated summing up scores from their 3 top A-level scores with A's gaining 10 points, B's, 8, C's, 6, D's, 4, and E's, 2.

Source: University Statistical Records Microdata (1972-1993), Higher Education Statistical Agency (1994-2005) and Times Higher Education Supplement (1996-1999) 


\section{Appendix Tables}

Table A.1. Description of Time Use Surveys

\begin{tabular}{cccccccc}
\hline Year & Age & $\begin{array}{c}\text { Diary } \\
\text { days }\end{array}$ & $\begin{array}{c}\text { Multi- } \\
\text { member }\end{array}$ & $\begin{array}{c}\text { Time } \\
\text { interval }\end{array}$ & $\begin{array}{c}\text { Original sample } \\
\text { size }\end{array}$ & $\begin{array}{c}\text { Main analysis } \\
\text { sample size }\end{array}$ & $\begin{array}{c}\text { Children } \\
\text { analysis sample } \\
\text { size }\end{array}$ \\
\hline 1974 & $5+$ & 7 & Yes & $30 \mathrm{~min}$. & 19490 & 4265 & 2881 \\
1983 & $14+$ & 7 & Yes & $15 \mathrm{~min}$. & 9206 & 2082 & 710 \\
1995 & $16+$ & 1 & No & $15 \mathrm{~min}$. & 1906 & 281 & $:$ \\
2000 & $8+$ & 2 & Yes & $10 \mathrm{~min}$. & 19400 & 3687 & 1216 \\
2005 & $16+$ & 1 & No & $10 \mathrm{~min}$. & 19400 & 688 & $:$ \\
\hline \hline
\end{tabular}

Source:MTUS (1983-2000) 
Table A.2. Activities in Total Time Investments, General Care, Teaching Care, and Playing Care

\begin{tabular}{|c|c|c|c|}
\hline Measure & Description & 1983 Survey & 2000 Survey \\
\hline Parental Time Investments & childcare & All & All \\
\hline \multirow[t]{10}{*}{ General Care } & physical, medical child & 1101 Feed and food preparation for babies and children & 3800 Unspecified childcare \\
\hline & care, supervise, & 1102 Wash, change babies & 3810 Unspecified physical care and supervision \\
\hline & care & 1103 Put children to bed/get them up & 3811 Feeding the child \\
\hline & & 1104 Babysit other people's children & 3819 Other specified physical care \\
\hline & & 1105 Other care of babies & 4270 Unspecified childcare as help \\
\hline & & 1106 Medical care of babies, children \& adults & 4271 Physical child care as help \\
\hline & & 1109 Supervising children & 3840 Accompanying child \\
\hline & & 1110 Other care of children & 3890 Other specified childcare \\
\hline & & 1111 Childcare-unspecified & 4274 Accompany child as help \\
\hline & & & 4279 Other specified childcare as help \\
\hline \multirow[t]{2}{*}{ Teaching Care } & teach, help with & 1108 Help children with homework & 3820 Teaching the child \\
\hline & homework & & 4272 Teaching a child as help \\
\hline \multirow[t]{2}{*}{ Playing Care } & read to, talk or play & 1107 Reading to, or playing with babies, children \& adults & 3830 Reading, playing and talking with child \\
\hline & with child & & 4273 Read/talk to child as help \\
\hline
\end{tabular}

Source:MTUS (1983-2000) 


\section{Table A.3. Activities in Children's Time Use. UK.}

1974 1983

\begin{tabular}{|c|c|c|c|}
\hline & 1974 & 1983 & 2000 \\
\hline School/classes & $\begin{array}{l}42 \text { At school, college } \\
79 \text { Evening classes }\end{array}$ & $\begin{array}{ll}0401 & \text { Educational activities - unspecified } \\
0402 & \text { Lunch break at educational establishment - school } \\
0403 & \text { Student at educational establishment } \\
0404 & \text { Other educational activities } \\
0405 & \text { Night and privately tutored classes for hobbies } \\
\end{array}$ & $\begin{array}{l}2000 \text { Unspecified study } \\
2100 \text { Unspecified activities related to school or university } \\
2110 \text { Classes and lectures } \\
2190 \text { Other specified activities related to school or university }\end{array}$ \\
\hline Homework & 61 Study & $\begin{array}{ll}3301 & \text { Studying } \\
3302 & \text { Computer activities (educational, programming) }\end{array}$ & $\begin{array}{l}2120 \text { Homework } \\
2210 \text { Free time study } \\
7220 \text { Computing-programming } \\
7230 \text { Unspecified computing for information } \\
7231 \text { Internet search } \\
7239 \text { Other information by computer } \\
7250 \text { Unspecified other computing } \\
7251 \text { Unspecified internet use }\end{array}$ \\
\hline Sports & 81 Play sport & $\begin{array}{l}1901 \text { Outdoor team games } \\
1902 \text { Non-team ball hitting sports } \\
1903 \text { Run, jog, cross-country, track and field } \\
1904 \text { Golf } \\
1905 \text { Fishing } \\
1906 \text { Bowls } \\
1907 \text { Martial arts } \\
1908 \text { Swimming and other water sports } \\
1909 \text { Keep fit, yoga, aerobics, dance practice } \\
1910 \text { Cycling } \\
1911 \text { Other outdoor sports } \\
1912 \text { Other indoor sports } \\
1913 \text { Horse rides } \\
1914 \text { Hunting, shooting, fishing etc. } \\
1915 \text { Other participation in sport and active leisure activities }\end{array}$ & $\begin{array}{l}6000 \text { Unspecified sports and outdoor activities } \\
6100 \text { Unspecified physical exercise } \\
6120 \text { Jogging and running } \\
6130 \text { Biking, skiing and skating (combined or unclear) } \\
6131 \text { Biking } \\
6132 \text { skiing or skating } \\
6140 \text { Unspecified ball games } \\
6141 \text { Indoor pairs or doubles games } \\
6142 \text { Indoor team games } \\
6143 \text { Outdoor pairs or doubles games } \\
6144 \text { Outdoor team games } \\
6149 \text { Other specified ball games } \\
6150 \text { Gymnastics } \\
6160 \text { Fitness } \\
6170 \text { Unspecified water sports } \\
6171 \text { Swimming } \\
6179 \text { Other specified water sports } \\
6190 \text { Other specified physical exercise } \\
6200 \text { Unspecified productive exercise } \\
6210 \text { Hunting and fishing } \\
6310 \text { Unspecified sports/prod exercise related activities } \\
6311 \text { Activities related to sports } \\
6312 \text { Activities related to productive exercise }\end{array}$ \\
\hline Travel & $\begin{array}{l}45 \text { Travel to work/school by car } \\
46 \text { Travel to/from work/school by other means } \\
47 \text { Travel to/from work/school, means unk } \\
48 \text { Travel as part of work }\end{array}$ & $\begin{array}{ll}0502 & \text { Travel to/from work } \\
0503 & \text { Education travel } \\
0504 & \text { Job search - travel } \\
0505 & \text { Other work-related travel }\end{array}$ & $\begin{array}{l}9110 \text { Travel in the course of work } \\
9130 \text { Travel to work from home and back only } \\
9140 \text { Travel to work from a place other than home } \\
9210 \text { Travel related to education } \\
9230 \text { Travel escorting to/from education }\end{array}$ \\
\hline
\end{tabular}

Source:MTUS (1974-2000) 
Table A. 4. Descriptive Statistics of Controls.

\begin{tabular}{|c|c|c|c|c|c|c|c|c|c|c|}
\hline & \multicolumn{5}{|c|}{ Mothers } & \multicolumn{5}{|c|}{ Fathers } \\
\hline & 1974 & 1983 & 1995 & 2000 & 2005 & 1974 & 1983 & 1995 & 2000 & 2005 \\
\hline \multirow[t]{2}{*}{ Some college or more } & 0.08 & 0.17 & 0.14 & 0.27 & 0.24 & 0.10 & 0.16 & 0.26 & 0.25 & 0.32 \\
\hline & $(0.3)$ & $(0.4)$ & $(0.3)$ & $(0.4)$ & $(0.4)$ & $(0.3)$ & $(0.4)$ & $(0.4)$ & $(0.4)$ & $(0.5)$ \\
\hline \multirow[t]{2}{*}{ Age 18-24 } & 0.11 & 0.10 & 0.03 & 0.06 & 0.04 & 0.18 & 0.13 & 0.06 & 0.10 & 0.10 \\
\hline & $(0.3)$ & $(0.3)$ & $(0.2)$ & $(0.2)$ & $(0.2)$ & $(0.4)$ & $(0.3)$ & $(0.2)$ & $(0.3)$ & $(0.3)$ \\
\hline \multirow[t]{2}{*}{ Age 25-34 } & 0.18 & 0.15 & 0.25 & 0.19 & 0.19 & 0.10 & 0.10 & 0.13 & 0.12 & 0.08 \\
\hline & $(0.4)$ & $(0.4)$ & $(0.4)$ & $(0.4)$ & $(0.4)$ & $(0.3)$ & $(0.3)$ & $(0.3)$ & $(0.3)$ & $(0.3)$ \\
\hline \multirow[t]{2}{*}{ Age 35-45 } & 0.42 & 0.54 & 0.57 & 0.48 & 0.56 & 0.34 & 0.39 & 0.51 & 0.42 & 0.45 \\
\hline & $(0.5)$ & $(0.5)$ & $(0.5)$ & $(0.5)$ & $(0.5)$ & $(0.5)$ & $(0.5)$ & $(0.5)$ & $(0.5)$ & $(0.5)$ \\
\hline \multirow[t]{2}{*}{ Age 45-54 } & 0.26 & 0.19 & 0.15 & 0.25 & 0.20 & 0.34 & 0.30 & 0.27 & 0.32 & 0.32 \\
\hline & $(0.4)$ & $(0.4)$ & $(0.4)$ & $(0.4)$ & $(0.4)$ & $(0.5)$ & $(0.5)$ & $(0.4)$ & $(0.5)$ & $(0.5)$ \\
\hline \multirow[t]{2}{*}{ Age 55-64 } & 0.04 & 0.02 & 0.00 & 0.01 & 0.01 & 0.03 & 0.08 & 0.04 & 0.05 & 0.05 \\
\hline & $(0.2)$ & $(0.1)$ & $(0.0)$ & $(0.1)$ & $(0.1)$ & $(0.2)$ & $(0.3)$ & $(0.2)$ & $(0.2)$ & $(0.2)$ \\
\hline \multirow[t]{2}{*}{ Married } & 0.85 & 0.76 & 0.66 & 0.73 & 0.59 & 0.78 & 0.86 & 0.90 & 0.87 & 0.84 \\
\hline & $(0.4)$ & $(0.4)$ & $(0.5)$ & $(0.4)$ & $(0.5)$ & $(0.4)$ & $(0.3)$ & $(0.3)$ & $(0.3)$ & $(0.4)$ \\
\hline \multirow[t]{2}{*}{ Number of children } & 1.86 & 1.79 & 1.73 & 1.81 & 1.68 & 2.00 & 1.87 & 1.62 & 1.81 & 1.66 \\
\hline & (1.0) & $(0.8)$ & $(0.7)$ & $(0.8)$ & $(0.7)$ & (1.1) & $(0.8)$ & $(0.7)$ & $(0.8)$ & $(0.7)$ \\
\hline N. obs & 2251 & 1307 & 165 & 2092 & 447 & 2104 & 775 & 116 & 1595 & 241 \\
\hline
\end{tabular}

Notes: This table shows means and standard deviations of controls used in the analysis by survey year. The samples include all mothers (all fathers) 18-64 who are not students or retired, where mother is defined as having a child under the age of 18 in the house. Sample weighting used.

Source:MTUS (1974-2005) 
Table A.5. Activities in Children's Time Use. US.

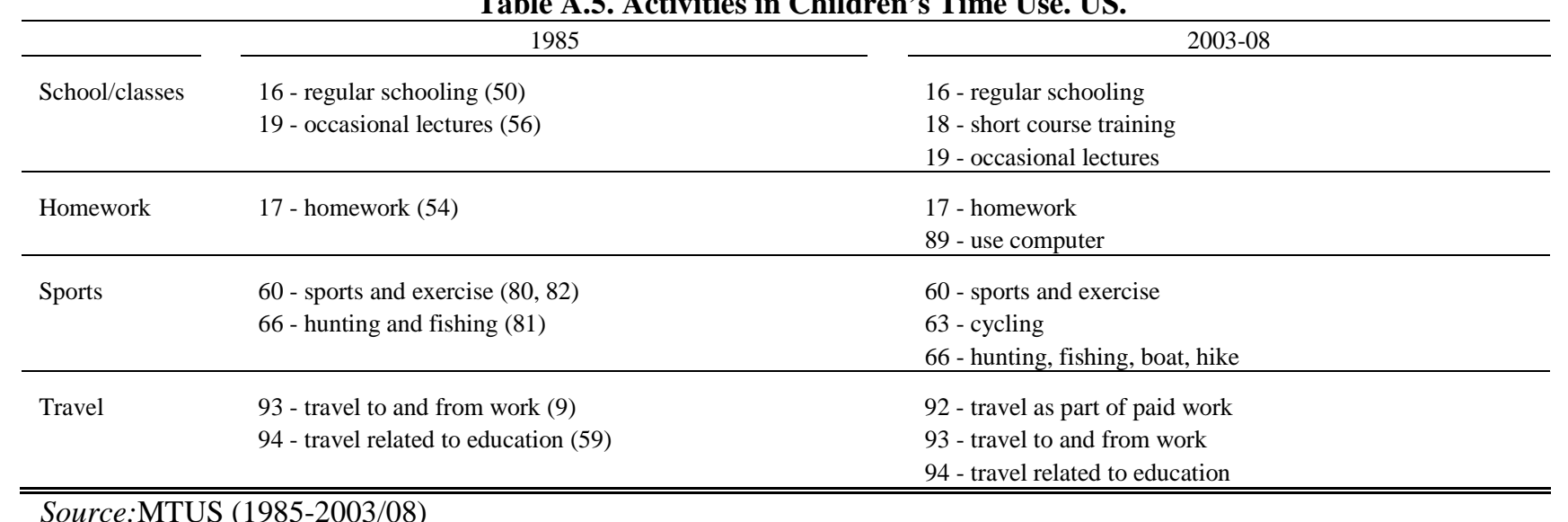

Source:MTUS (1985-2003/08) 
Table A.6. Descriptive Statistics of ICVS Sample.

\begin{tabular}{|c|c|c|c|c|c|c|c|c|}
\hline & \multicolumn{4}{|c|}{ Women } & \multicolumn{4}{|c|}{ Men } \\
\hline & 1989 & 1996 & 2000 & 2005 & 1989 & 1996 & 2000 & 2005 \\
\hline \multirow[t]{2}{*}{ Feelings of unsafety } & & 0.12 & 0.10 & 0.12 & & 0.04 & 0.02 & 0.06 \\
\hline & & $(0.3)$ & $(0.3)$ & $(0.3)$ & & $(0.2)$ & $(0.1)$ & $(0.2)$ \\
\hline \multirow[t]{2}{*}{ Likelihood of burglary } & 0.08 & 0.13 & 0.06 & 0.09 & 0.08 & 0.08 & 0.05 & 0.05 \\
\hline & $(0.3)$ & $(0.3)$ & $(0.2)$ & $(0.3)$ & $(0.3)$ & $(0.3)$ & $(0.2)$ & $(0.2)$ \\
\hline \multirow[t]{2}{*}{ Some college or more } & 0.28 & 0.22 & 0.27 & 0.42 & 0.42 & 0.28 & 0.38 & 0.42 \\
\hline & $(0.4)$ & $(0.4)$ & $(0.4)$ & $(0.5)$ & $(0.5)$ & $(0.4)$ & $(0.5)$ & $(0.5)$ \\
\hline \multirow[t]{2}{*}{ Age 18-24 } & 0.16 & 0.09 & 0.13 & 0.08 & 0.16 & 0.10 & 0.13 & 0.10 \\
\hline & $(0.4)$ & $(0.3)$ & $(0.3)$ & $(0.3)$ & $(0.4)$ & $(0.3)$ & $(0.3)$ & $(0.3)$ \\
\hline \multirow[t]{2}{*}{ Age 25-34 } & 0.15 & 0.19 & 0.15 & 0.13 & 0.12 & 0.16 & 0.19 & 0.12 \\
\hline & $(0.4)$ & $(0.4)$ & $(0.4)$ & $(0.3)$ & $(0.3)$ & $(0.4)$ & $(0.4)$ & $(0.3)$ \\
\hline \multirow[t]{2}{*}{ Age 35-45 } & 0.25 & 0.28 & 0.25 & 0.32 & 0.23 & 0.27 & 0.25 & 0.28 \\
\hline & $(0.4)$ & $(0.4)$ & $(0.4)$ & $(0.5)$ & $(0.4)$ & $(0.4)$ & $(0.4)$ & $(0.4)$ \\
\hline \multirow[t]{2}{*}{ Age 45-54 } & 0.15 & 0.21 & 0.23 & 0.19 & 0.16 & 0.22 & 0.21 & 0.21 \\
\hline & $(0.4)$ & $(0.4)$ & $(0.4)$ & $(0.4)$ & $(0.4)$ & $(0.4)$ & $(0.4)$ & $(0.4)$ \\
\hline \multirow[t]{2}{*}{ Age 55-64 } & 0.16 & 0.11 & 0.11 & 0.15 & 0.20 & 0.12 & 0.12 & 0.17 \\
\hline & $(0.4)$ & $(0.3)$ & $(0.3)$ & $(0$. & $(0.4)$ & $(0.3)$ & $(0.3)$ & $(0.4)$ \\
\hline \multirow[t]{2}{*}{ Married } & 0.00 & 0.61 & 0.48 & 0.63 & 0.00 & 0.63 & 0.48 & 0.56 \\
\hline & $(0.0)$ & $(0.5)$ & $(0.5)$ & $(0.5$ & $(0.0)$ & $(0.5)$ & $(0.5)$ & $(0.5)$ \\
\hline \multirow[t]{2}{*}{ Children in the household } & 0.48 & 0.54 & 0.02 & 0.00 & 0.41 & 0.43 & 0.02 & 0.00 \\
\hline & (0.5) & $(0.5)$ & $(0.1)$ & $(0.0)$ & $(0.5)$ & $(0.5)$ & $(0.1)$ & $(0.0)$ \\
\hline N. obs & 2631 & 1997 & 2082 & 759 & 2264 & 1790 & 1715 & 562 \\
\hline
\end{tabular}

Notes: This table shows means and standard deviations of dependent variables and controls used in the analysis by survey year. The samples include all women (all men) 18-64 who are not students or retired. Sample weighting used.

Source: International Crime Victims Survey Data, 1989-2005. 
Table A. 7. Descriptive Statistics of WVS and EVS Sample.

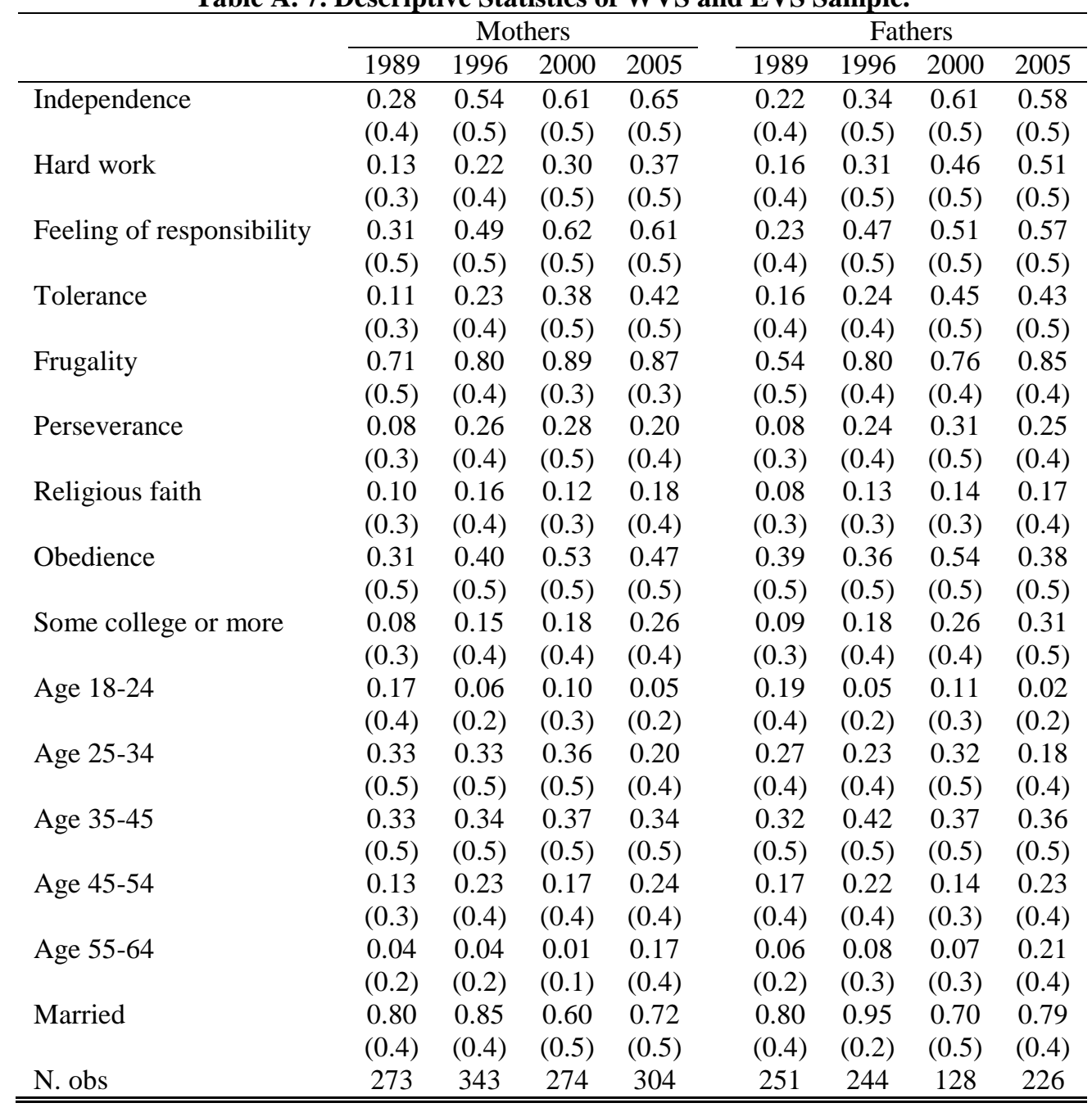

Notes: This table shows means and standard deviations of dependent variables and controls used in the analysis by survey year. The samples include all mothers (all fathers 18-64 who are not students or retired. Sample weighting used.

Source: European Values Study (1981, 1990, and 1999) and World Values Survey Data, 2005. 
Table A.8. Parenting Values Index Loading Factors. UK (1981-2005).

\begin{tabular}{lcc}
\hline & $(1)$ & $(2)$ \\
& Mothers & Fathers \\
\hline Independence & 0.479 & 0.749 \\
Hard work & 0.303 & 0.255 \\
Feeling of responsibility & 0.285 & 0.454 \\
Imagination & 0.343 & 0.512 \\
Tolerance & -0.072 & 0.023 \\
Frugality & 0.181 & 0.043 \\
Religious faith & -0.246 & -0.260 \\
Obedience & -0.364 & -0.549 \\
\hline Proportion of variance & 17.17 & 18.73 \\
\hline \hline
\end{tabular}

Notes: This table shows the weights assigned to each variable for the first principal component in constructing mothers' and fathers' composite measures of parenting values. The three highest factor loadings are shaded in grey. The last row also shows the proportion of variance attributable to the first principal component.

Source: European Values Study $(1981,1990,1999)$ and World Values Survey $(2005)$. 
Table A.9. Trends in Parental Time Investments by Educational Attainment and Age of Youngest Child. UK (1974-2005)

\begin{tabular}{|c|c|c|c|c|}
\hline & \multicolumn{2}{|l|}{$(1)$} & \multirow{2}{*}{\multicolumn{2}{|c|}{$\begin{array}{c}\text { (3) } \\
\text { Families with youngest child 5-10 }\end{array}$}} \\
\hline & \multicolumn{2}{|c|}{ Families with youngest child under 5} & & \\
\hline & Mothers & Fathers & \multirow[t]{2}{*}{ Mothers } & \multirow[t]{2}{*}{ Fathers } \\
\hline \multicolumn{3}{|l|}{ Panel A. Year dummies } & & \\
\hline \multirow[t]{2}{*}{ year_1974 } & $-6.38 * * *$ & $-1.84 * * *$ & $-2.60 * * *$ & $-1.05 * * *$ \\
\hline & $(0.064)$ & $(0.070)$ & $(0.025)$ & $(0.033)$ \\
\hline year_1983 & ref. & ref. & ref. & ref. \\
\hline \multirow[t]{2}{*}{ year_1995 } & $4.52 * * *$ & $5.02 * * *$ & $4.20 * * *$ & $3.74 * * *$ \\
\hline & $(0.230)$ & $(0.082)$ & $(0.095)$ & $(0.055)$ \\
\hline \multirow{2}{*}{ year_2000 } & $2.38 * * *$ & $3.31 * * *$ & $1.08 * * *$ & $0.95 * * *$ \\
\hline & $(0.094)$ & $(0.115)$ & $(0.041)$ & $(0.047)$ \\
\hline \multirow[t]{2}{*}{ year_2005 } & $7.68 * * *$ & $9.10 * * *$ & $5.47 * * *$ & $3.86 * * *$ \\
\hline & $(0.262)$ & $(0.047)$ & $(0.108)$ & $(0.028)$ \\
\hline \multicolumn{5}{|l|}{ Panel B. College educated } \\
\hline \multirow[t]{2}{*}{ Some college or more } & $3.74 * * *$ & $4.04 * * *$ & $1.42^{* * *}$ & -0.18 \\
\hline & $(0.173)$ & $(0.077)$ & $(0.102)$ & $(0.234)$ \\
\hline \multicolumn{5}{|l|}{ Panel C. Interaction terms } \\
\hline \multirow[t]{2}{*}{ Some college*year_1974 } & $-3.37 * * *$ & $-4.32 * * *$ & $-1.11 * * *$ & $0.52 *$ \\
\hline & $(0.211)$ & $(0.051)$ & $(0.081)$ & $(0.227)$ \\
\hline Some college*year_1983 & ref. & ref. & ref. & ref. \\
\hline \multirow[t]{2}{*}{ Some college*year_1995 } & $-4.61 * * *$ & $-0.41^{* *}$ & $3.99 * * *$ & $2.42 * * *$ \\
\hline & $(0.308)$ & $(0.136)$ & $(0.113)$ & $(0.364)$ \\
\hline \multirow[t]{2}{*}{ Some college*year_2000 } & $-0.79 * *$ & $-2.57 * * *$ & $-0.71 * * *$ & 0.50 \\
\hline & $(0.173)$ & $(0.071)$ & $(0.061)$ & $(0.314)$ \\
\hline \multirow[t]{2}{*}{ Some college*year_2005 } & $-3.95 * * *$ & $-4.85 * * *$ & $-2.44 * * *$ & -0.06 \\
\hline & $(0.237)$ & $(0.072)$ & $(0.077)$ & $(0.195)$ \\
\hline \multirow[t]{2}{*}{ constant } & $12.60 * * *$ & $5.47 * *$ & $5.03 * * *$ & 3.45 \\
\hline & $(2.045)$ & $(1.858)$ & $(0.546)$ & $(1.670)$ \\
\hline
\end{tabular}

Notes: Each column comes from a different regression. The equation is $C T_{i t}=\beta_{1} H_{i t}+H_{i t} \mathbf{T}_{\mathbf{t}} \boldsymbol{\beta}_{2}+\mathbf{X}_{\mathbf{i t}} \boldsymbol{\beta}_{3}+\delta_{t}+\varepsilon_{i t}$. In all specifications $C T_{i t}$ is total time in hours per week devoted to childcare $H_{i t}$ is a dummy variable of parental education (=1 college educated), $\mathbf{T}_{\mathbf{t}}$ is a vector of dummies for the survey year, $\delta_{t}$ are survey-period fixed effects, and $\varepsilon_{i t}$ is the error term clustered at the survey level. $X_{\text {it }}$ includes controls parents' ages, marital status, a quadratic in the number of children, and a vector of dummies to control for the day of the week the diary was reported, ref. 24-35 year-olds, Sunday). The omitted year is labelled ref. in each column. In columns (1) and (2) the sample includes mothers (fathers) 18-64 who are not students or retired, co-resident with at least a child 5-15 in the house and no children under 5; in columns (3) and (4) the samples include mothers (fathers) 18-64 who are not students or retired, co-resident with at least a child under 5 years old. Standard errors in parentheses.* significant at $10 \% * *$ significant at $5 \%$; *** significant at $1 \%$.

\section{Source:MTUS (1974-2005)}

*** Significant at the 1 percent level.

** Significant at the 5 percent level. 
Table A.10. Total Enrolment and Proportion of Enrolment in Different Groups of Institutions

\begin{tabular}{|c|c|c|c|c|c|c|c|c|c|}
\hline \multirow{4}{*}{ Year } & \multirow{4}{*}{$\begin{array}{c}\text { All Universities } \\
(1) \\
\text { Enrolment }\end{array}$} & \multirow{4}{*}{$\begin{array}{c}\text { Pre-92 Universities } \\
(2) \\
\text { Enrolment }\end{array}$} & \multicolumn{2}{|c|}{ Oxbridge } & \multicolumn{3}{|c|}{ Ancient and Civic Universties } & \multicolumn{2}{|c|}{ Russell Group } \\
\hline & & & (3) & (4) & (5) & (6) & (7) & (8) & (9) \\
\hline & & & Enrolment & Proportion & Enrolment & Proportion & Proportion & Enrolment & Proportion \\
\hline & & & & Out of pre-92 & & Out of pre-92 & Out of All & & Out of pre-92 \\
\hline 1974 & 214,746 & 214,746 & 17,661 & 0.082 & 80,603 & 0.375 & 0.375 & 98,636 & 0.459 \\
\hline 1975 & 224,166 & 224,166 & 17,933 & 0.080 & 82,742 & 0.369 & 0.369 & 101,915 & 0.455 \\
\hline 1976 & 234,773 & 234,773 & 18,427 & 0.078 & 85,462 & 0.364 & 0.364 & 105,968 & 0.451 \\
\hline 1977 & 245,798 & 245,798 & 18,767 & 0.076 & 87,584 & 0.356 & 0.356 & 109,777 & 0.447 \\
\hline 1978 & 254,058 & 254,058 & 19,117 & 0.075 & 89,384 & 0.352 & 0.352 & 112,595 & 0.443 \\
\hline 1979 & 261,093 & 261,093 & 19,256 & 0.074 & 91,266 & 0.350 & 0.350 & 116,195 & 0.445 \\
\hline 1980 & 267,566 & 267,566 & 19,362 & 0.072 & 93,281 & 0.349 & 0.349 & 119,305 & 0.446 \\
\hline 1981 & 270,168 & 270,168 & 19,597 & 0.073 & 94,308 & 0.349 & 0.349 & 121,348 & 0.449 \\
\hline 1982 & 268,085 & 268,085 & 19,536 & 0.073 & 93,316 & 0.348 & 0.348 & 120,604 & 0.450 \\
\hline 1983 & 263,053 & 263,053 & 19,391 & 0.074 & 92,803 & 0.353 & 0.353 & 120,103 & 0.457 \\
\hline 1984 & 266,352 & 266,352 & 19,519 & 0.073 & 92,786 & 0.348 & 0.348 & 120,098 & 0.451 \\
\hline 1985 & 267,953 & 267,953 & 19,915 & 0.074 & 93,696 & 0.350 & 0.350 & 120,683 & 0.450 \\
\hline 1986 & 271,848 & 271,848 & 20,192 & 0.074 & 94,656 & 0.348 & 0.348 & 121,778 & 0.448 \\
\hline 1987 & 276,462 & 276,462 & 20,366 & 0.074 & 95,599 & 0.346 & 0.346 & 123,509 & 0.447 \\
\hline 1988 & 286,016 & 286,016 & 20,607 & 0.072 & 98,030 & 0.343 & 0.343 & 127,194 & 0.445 \\
\hline 1989 & 301,870 & 301,870 & 21,005 & 0.070 & 103,073 & 0.341 & 0.341 & 133,206 & 0.441 \\
\hline 1990 & 317,777 & 317,777 & 21,410 & 0.067 & 108,318 & 0.341 & 0.341 & 139,921 & 0.440 \\
\hline 1991 & 341,616 & 341,616 & 21,444 & 0.063 & 114,887 & 0.336 & 0.336 & 148,825 & 0.436 \\
\hline 1992 & 371,638 & 371,638 & 21,543 & 0.058 & 123,487 & 0.332 & 0.332 & 159,729 & 0.430 \\
\hline 1993 & 402,069 & 402,069 & 21,730 & 0.054 & 132,573 & 0.330 & 0.330 & 171,162 & 0.426 \\
\hline 1994 & 943,239 & 426,283 & 21,345 & 0.050 & 134,313 & 0.315 & 0.142 & 173,058 & 0.406 \\
\hline 1995 & 972,493 & 441,601 & 21,725 & 0.049 & 136,130 & 0.308 & 0.140 & 178,689 & 0.405 \\
\hline 1996 & 997,661 & 461,565 & 21,981 & 0.048 & 140,866 & 0.305 & 0.141 & 184,775 & 0.400 \\
\hline 1997 & $1,022,606$ & 475,868 & 22,178 & 0.047 & 144,108 & 0.303 & 0.141 & 191,755 & 0.403 \\
\hline 1998 & $1,032,897$ & 485,911 & 22,451 & 0.046 & 148,146 & 0.305 & 0.143 & 198,646 & 0.409 \\
\hline 1999 & $1,027,450$ & 486,250 & 22,780 & 0.047 & 148,220 & 0.305 & 0.144 & 200,430 & 0.412 \\
\hline 2000 & $1,037,870$ & 490,060 & 22,485 & 0.046 & 149,280 & 0.305 & 0.144 & 202,220 & 0.413 \\
\hline 2001 & $1,069,215$ & 509,345 & 23,325 & 0.046 & 155,550 & 0.305 & 0.145 & 211,460 & 0.415 \\
\hline 2002 & 1,111,305 & 532,385 & 23,410 & 0.044 & 162,440 & 0.305 & 0.146 & 221,410 & 0.416 \\
\hline 2003 & $1,141,840$ & 549,350 & 23,400 & 0.043 & 166,760 & 0.304 & 0.146 & 228,545 & 0.416 \\
\hline 2004 & $1,165,465$ & 564,755 & 23,455 & 0.042 & 174,425 & 0.309 & 0.150 & 238,985 & 0.423 \\
\hline 2005 & $1,198,810$ & 575,090 & 24,055 & 0.042 & 175,925 & 0.306 & 0.147 & 242,700 & 0.422 \\
\hline 1974-2005 & $18,327,958$ & $11,605,570$ & 669,368 & 0.058 & $3,784,017$ & 0.326 & 0.206 & $4,965,224$ & 0.428 \\
\hline
\end{tabular}

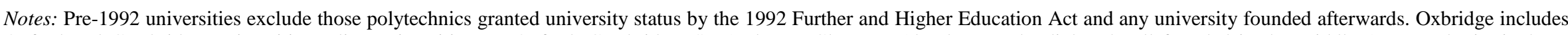



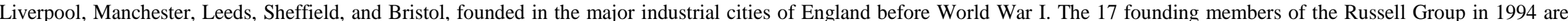

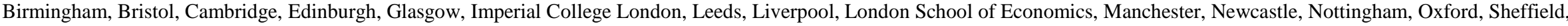

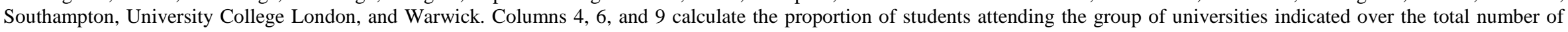
students attending pre-92 institutions. Column 7 calculates this proportion over the total number of students attending all universities, including post-1992 institutions.

Source: University Statistical Records Microdata (1972-1993) and Higher Education Statistical Agency (1994-2005) 
Table A.11. Average Scores and Relative Scores in Different Groups of Institutions

\begin{tabular}{|c|c|c|c|c|c|c|c|}
\hline \multirow{4}{*}{ Year } & \multirow{4}{*}{$\begin{array}{c}\text { Pre-92 Universities } \\
(1) \\
\text { Average } \\
\text { Scores }\end{array}$} & \multicolumn{2}{|c|}{ Oxbridge } & \multicolumn{2}{|c|}{ Ancient and Civic Universties } & \multicolumn{2}{|c|}{ Russel Group } \\
\hline & & (2) & (3) & (4) & (5) & (6) & (7) \\
\hline & & Average & Relative & Average & Relative & Average & Relative \\
\hline & & Scores & Scores & Scores & Scores & Scores & Scores \\
\hline 1974 & 16.58 & 24.00 & 1.448 & 17.73 & 1.069 & 18.58 & 1.121 \\
\hline 1975 & 16.55 & 24.00 & 1.450 & 17.74 & 1.072 & 18.51 & 1.118 \\
\hline 1976 & 16.56 & 24.17 & 1.459 & 18.02 & 1.088 & 18.57 & 1.121 \\
\hline 1977 & 16.67 & 24.46 & 1.468 & 18.43 & 1.106 & 18.72 & 1.123 \\
\hline 1978 & 16.70 & 24.60 & 1.473 & 18.56 & 1.111 & 18.82 & 1.127 \\
\hline 1979 & 16.82 & 24.82 & 1.476 & 18.71 & 1.112 & 18.94 & 1.126 \\
\hline 1980 & 17.01 & 25.03 & 1.471 & 18.92 & 1.112 & 19.17 & 1.127 \\
\hline 1981 & 17.36 & 25.29 & 1.457 & 19.28 & 1.110 & 19.53 & 1.125 \\
\hline 1982 & 17.66 & 25.31 & 1.433 & 19.32 & 1.094 & 19.69 & 1.115 \\
\hline 1983 & 18.12 & 25.14 & 1.387 & 19.56 & 1.079 & 20.05 & 1.107 \\
\hline 1984 & 17.90 & 25.18 & 1.407 & 19.79 & 1.106 & 20.29 & 1.134 \\
\hline 1985 & 18.13 & 25.35 & 1.398 & 19.94 & 1.100 & 20.39 & 1.125 \\
\hline 1986 & 18.10 & 25.50 & 1.409 & 19.91 & 1.100 & 20.39 & 1.126 \\
\hline 1987 & 17.93 & 25.64 & 1.430 & 19.72 & 1.100 & 20.21 & 1.127 \\
\hline 1988 & 17.53 & 25.78 & 1.471 & 19.42 & 1.108 & 19.98 & 1.140 \\
\hline 1989 & 17.23 & 25.97 & 1.508 & 19.26 & 1.118 & 19.86 & 1.153 \\
\hline 1990 & 17.17 & 26.01 & 1.515 & 19.15 & 1.115 & 19.78 & 1.152 \\
\hline 1991 & 17.11 & 26.24 & 1.534 & 19.18 & 1.121 & 19.73 & 1.153 \\
\hline 1992 & 16.58 & 26.26 & 1.584 & 18.64 & 1.124 & 19.35 & 1.167 \\
\hline 1993 & 16.17 & 26.25 & 1.623 & 18.25 & 1.129 & 18.98 & 1.174 \\
\hline 1996 & 19.29 & 27.14 & 1.407 & 22.45 & 1.164 & 22.57 & 1.170 \\
\hline 1997 & 20.13 & 27.44 & 1.363 & 23.01 & 1.143 & 23.04 & 1.144 \\
\hline 1998 & 20.36 & 27.49 & 1.350 & 23.21 & 1.140 & 23.24 & 1.142 \\
\hline 1999 & 20.29 & 27.59 & 1.360 & 22.77 & 1.122 & 23.14 & 1.141 \\
\hline 1974-1993/1996-1999 & 17.19 & 25.25 & 1.469 & 18.98 & 1.104 & 19.48 & 1.133 \\
\hline
\end{tabular}

Notes: Oxbridge includes Oxford and Cambridge Universities. Ancient and Civic Universities are Oxford, Cambridge, St. Andrews, Glasgow, Aberdeen, and Edinburgh, all founded in the Middle Ages, and Birmingham, Liverpool, Manchester, Leeds, Sheffield, and Bristol, founded in the major industrial cities of England before World War I. The 17 founding members of the Russell Group in 1994 are Birmingham, Bristol, Cambridge, Edinburgh, Glasgow, Imperial College London, Leeds, Liverpool, London School of Economics, Manchester, Newcastle, Nottingham, Oxford, Sheffield, Southampton, University College London, and Warwick. Columns 3, 5, and 7 show the ratio of average scores of students enrolled at elite universities to average scores of all students. The sample includes students with A-level scores as entry qualifications. Individual students' scores are calculated summing up scores from their 3 top A-level scores with A's gaining 10 points, B's, 8, C's, 6, D's, 4, and E's, 2 in USR and two points more, from 12 to 4, in THES.

Source: University Statistical Records Microdata (1972-1993) and Times Higher Education Supplement (1996-1999). 
Table A.12 - Trends in Parental Time Investments by Educational Attainment and Region. UK (1974-2005)

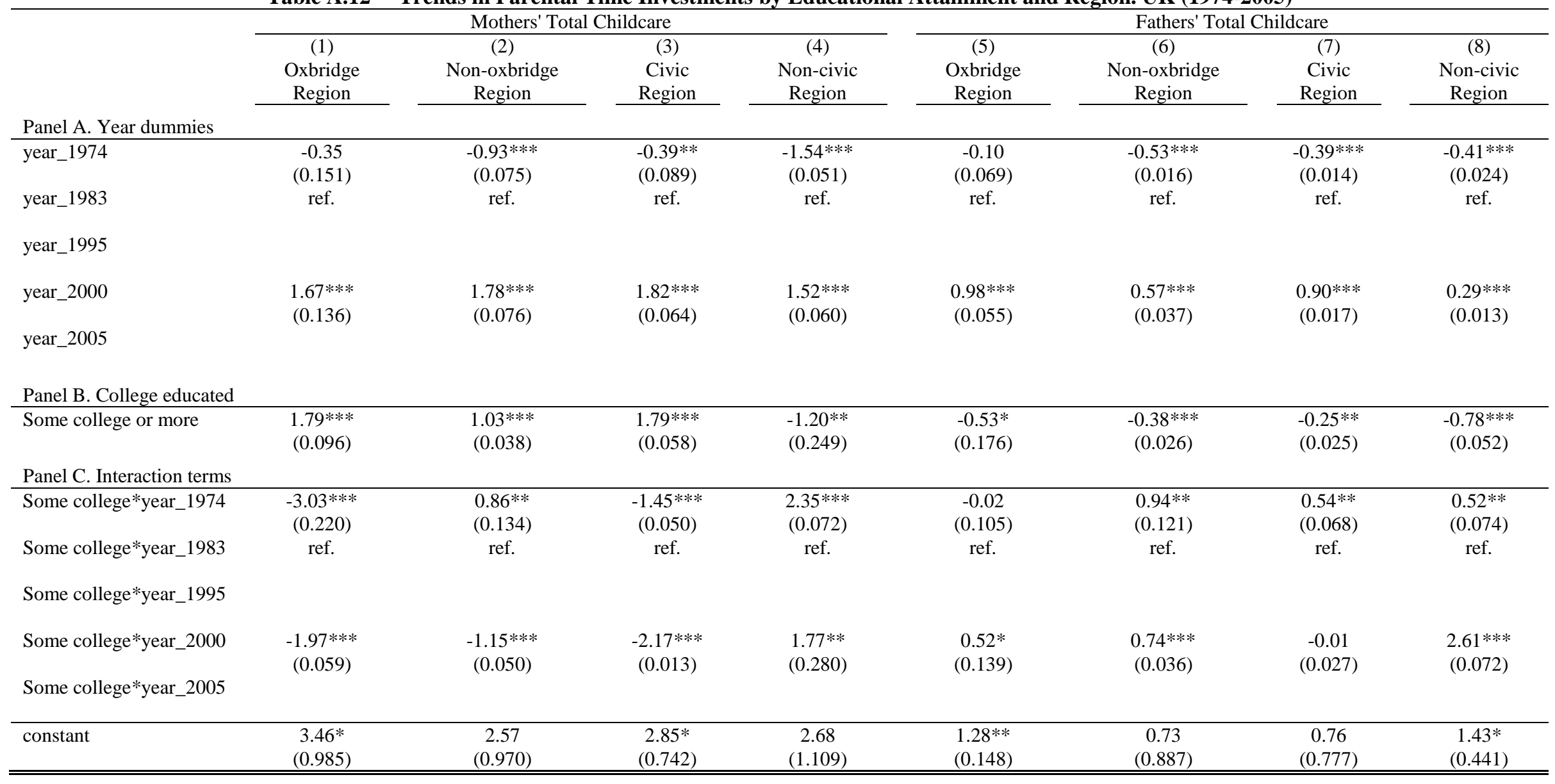

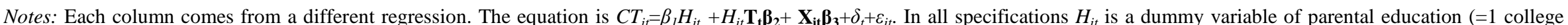

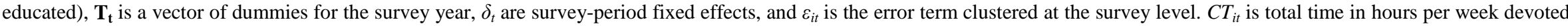

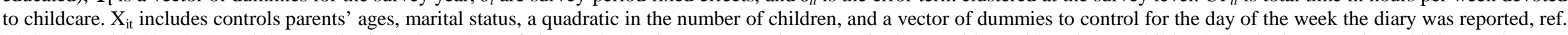

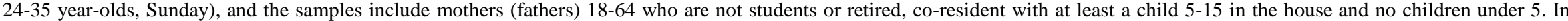

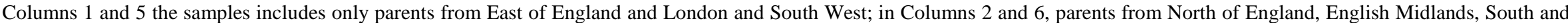

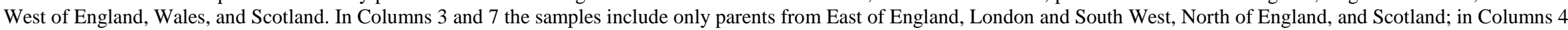
and 8, parents from English Midlands, South and West of England, and Wales. The omitted year is labelled ref. in each column.

Source:MTUS (1974-2005)

*** Significant at the 1 percent level. ** Significant at the 5 percent level. 